\title{
Associations between immune-suppressive and stimulating drugs and novel COVID-19-a systematic review of current evidence
}

\author{
Beth Russell ${ }^{1, *}$, Charlotte Moss ${ }^{1, *}$, Gincy George ${ }^{1,{ }^{*}}$, Aida Santaolalla ${ }^{1,{ }^{*}}$, Andrew Cope ${ }^{2,3}$, Sophie Papa ${ }^{2,4,{ }^{* *}}$ and Mieke Van Hemelrijck ${ }^{1,{ }^{* *}}$ \\ ${ }^{1}$ Translational Oncology and Urology Research, King's College London, London, UK \\ ${ }^{2}$ Guy's and St. Thomas NHS Foundation Trust, London, UK \\ ${ }^{3}$ Centre for Rheumatic Diseases, King's College London, London, UK \\ ${ }^{4}$ School of Cancer and Pharmaceutical Sciences, King's College London, London, UK \\ ${ }^{*}$ All authors contributed equally. \\ ${ }^{* *}$ Both senior authors contributed equally.
}

\section{Abstract}

Background: Cancer and transplant patients with COVID-19 have a higher risk of developing severe and even fatal respiratory diseases, especially as they may be treated with immune-suppressive or immune-stimulating drugs. This review focuses on the effects of these drugs on host immunity against COVID-19.

Methods: Using Ovid MEDLINE, we reviewed current evidence for immune-suppressing or -stimulating drugs: cytotoxic chemotherapy, low-dose steroids, tumour necrosis factora (TNFa) blockers, interlukin-6 (IL-6) blockade, Janus kinase (JAK) inhibitors, IL-1 blockade, mycophenolate, tacrolimus, anti-CD20 and CTLA4-lg.

Results: 89 studies were included. Cytotoxic chemotherapy has been shown to be a specific inhibitor for severe acute respiratory syndrome coronavirus in in vitro studies, but no specific studies exist as of yet for COVID-19. No conclusive evidence for or against the use of non-steroidal anti-inflammatory drugs (NSAIDs) in the treatment of COVID-19 patients is available, nor is there evidence indicating that TNFa blockade is harmful to patients in the context of COVID-19. COVID-19 has been observed to induce a proinflammatory cytokine generation and secretion of cytokines, such as IL-6, but there is no evidence of the beneficial impact of IL- 6 inhibitors on the modulation of COVID-19. Although there are potential targets in the JAK-STAT pathway that can be manipulated in treatment for coronaviruses and it is evident that IL-1 is elevated in patients with a coronavirus, there is currently no evidence for a role of these drugs in treatment of COVID-19.

Conclusion: The COVID-19 pandemic has led to challenging decision-making about treatment of critically unwell patients. Low-dose prednisolone and tacrolimus may have beneficial impacts on COVID-19. The mycophenolate mofetil picture is less clear, with conflicting data from pre-clinical studies. There is no definitive evidence that specific cytotoxic drugs, low-dose methotrexate for auto-immune disease, NSAIDs, JAK kinase inhibitors or anti-TNFa agents are contraindicated. There is clear evidence that IL-6 peak levels are associated with severity of pulmonary complications.

Keywords: immune modulation, immune suppression, cancer, COVID-19, adverse events
Correspondence to: Mieke Van Hemelrijck Email: mieke.vanhemelrijck@kcl.ac.uk

ecancer 2020, 14:1022

https://doi.org/10.3332/ecancer.2020.1022

Published: $27 / 03 / 2020$

Received: 20/03/2020

Publication costs for this article were supported by ecancer (UK Charity number 1176307).

Copyright: $($ ) the authors; licensee ecancermedicalscience. This is an Open Access article distributed under the terms of the Creative Commons Attribution License (http:// creativecommons.org/licenses/by/3.0), which permits unrestricted use, distribution, and reproduction in any medium, provided the original work is properly cited. 


\section{Introduction}

Since the outbreak of severe acute respiratory syndrome (SARS)-CoV-2 or COVID-19 coronavirus started in China in December 2019, there is increasing evidence that those with existing comorbidities, older age or a compromised immune system are at higher risk of developing severe and even fatal respiratory diseases [1]. Cancer and transplant patients are also considered to be in this risk group [2, 3], especially as they may be treated with immune-suppressive or immune-stimulating drugs.

The current review focuses on the effects of immune-suppressive or immune-stimulating drugs on the host immunity against COVID-19. Here, we report a short introduction to each drug, followed by a summary of the results from the identified studies for each relative drug.

We hypothesise that the drugs selected will likely be categorised into one of two groups: 1) those that may be harmful for patients and put them at risk of increased morbidity/mortality associated with COVID-19 infection and 2) those that may be used to treat the immunopathology associated with severe persistent viral infection. The clinical impact of this review is, thus, twofold. It aims to identify which drugs clinicians should be thinking about taking patients off to protect them from increased harm from COVID-19 and also which drugs could be potentially beneficial in the fight against the disease.

This review covers the information available today. As the COVID-19 pandemic progresses, there is an opportunity and responsibility to collect prospective data using established randomised controlled trial involving drugs of interest and cohort-based translational studies.

1) All cytotoxic chemotherapy

2) Low-dose steroids and non-steroidal anti-inflammatory drugs (NSAIDs)

3) Any tumour necrosis factor (TNF) blocker

4) interlukin-6 (IL-6) blockade

5) Janus kinase (JAK) inhibitors

6) IL-1 blockade

7) Mycophenolate

8) Tacrolimus

9) Anti-CD20

10) CTLA4-Ig

\section{Methods}

A search was conducted using Ovid MEDLINE and a total of 89 studies were included in this review for 10 different types of immunesuppressing or immune-stimulating drug groups. Table 1 shows the search terms and the number of studies included in the review.

Table 1. Search terms and the number of studies included for each investigated drug group.

\begin{tabular}{|l|l|c|}
\hline \multicolumn{1}{|c|}{ Drug group } & \multicolumn{1}{|c|}{ Search terms } & $\begin{array}{c}\text { Number of studies } \\
\text { included }\end{array}$ \\
\hline $\begin{array}{l}\text { All cytotoxic } \\
\text { chemotherapy }\end{array}$ & $\begin{array}{l}\text { (SARS-CoV-2 or coronavirus or COVID or betacoronavirus or Middle East } \\
\text { Respiratory Syndrome Coronavirus (MERS-CoV) or SARS-CoV AND } \\
\text { chemotherapy) }\end{array}$ & $24 / 30$ \\
\hline $\begin{array}{l}\text { Low-dose steroids/ } \\
\text { NSAIDs }\end{array}$ & $\begin{array}{l}\text { (SARS-CoV-2 or coronavirus or COVID or betacoronavirus or MERS-CoV or } \\
\text { SARS-CoV) AND (anti-inflammatory or ibuprofen or isobutylphenylpropionic } \\
\text { acid or cortisone or non-steroidal anti-inflammatory) }\end{array}$ & $13 / 58$ \\
\hline Any TNF blocker & $\begin{array}{l}\text { ((SARS-CoV-2 or coronavirus or COVID or betacoronavirus or MERS-CoV or } \\
\text { SARS-CoV) AND (TNF blocker or Anti-TNF therapy or TNFa inhibitor or inflix- } \\
\text { imab or etanercept or Certolizumab or Golimumab or adalimumab)) }\end{array}$ & $2 / 3$ \\
\hline
\end{tabular}


Table 1. Search terms and the number of studies included for each investigated drug group. (continued)

\begin{tabular}{|c|c|c|}
\hline IL-6 blockade & $\begin{array}{l}\text { Two different search strategies were explored due to the number of agents } \\
\text { that block the IL-6: } \\
\text { 1. ((SARS-CoV-2 or coronavirus or COVID or betacoronavirus or MERS-CoV } \\
\text { or SARS-CoV) AND (Anti-IL-6 therapy or anti-interleukin-6 receptor anti- } \\
\text { body or anti-interlukin-6 therapy or interlukin } 6 \text { blockage or interlukin-6 } \\
\text { blockage or IL } 6 \text { blockage or IL-6 blockage or tocilizumab or siltuximab or } \\
\text { Sylvant or sarilumab or olokizumab or CDP6038 or elsilimomab or BMS- } \\
945429 \text { or ALD518 or sirukumab or CNTO } 136 \text { or CPSI-2364 or ALX-0061 } \\
\text { or clazakizumab or olokizumab or sarilumab or sirukumab or ARGX-109 or } \\
\text { FE301 or FM101)) } \\
\text { 2. ((SARS-CoV-2 or coronavirus or COVID or betacoronavirus or MERS-CoV } \\
\text { or SARS-CoV) and (IL-6 or interlukin } 6 \text { or Anti-IL-6 therapy or IL-6 blockage } \\
\text { or tocilizumab or siltuximab)) }\end{array}$ & $\begin{array}{c}0 \\
23 / 108\end{array}$ \\
\hline JAK inhibitors & $\begin{array}{l}\text { ((SARS-CoV-2 or coronavirus or COVID or betacoronavirus or MERS-CoV or } \\
\text { SARS-CoV) and (JAK or JAK1 or JAK } 2 \text { or TYK3 or tofacitinib or baricitinib or } \\
\text { filgotinib or peficitinib or ABT494 or decernotinib)) }\end{array}$ & $4 / 15$ \\
\hline IL-1 blockade & $\begin{array}{l}\text { (SARS-CoV-2 or coronavirus or COVID or betacoronavirus or MERS-CoV or } \\
\text { SARS-CoV) AND (Interleukin-1 or IL-1 or IL-1RA or canakinumab or anti-IL-1 } \\
\text { or IL-1 antagonists or IL-1 blockers or rilonacept or IL-1 trap or ACZ885 or } \\
\text { anakinra) }\end{array}$ & $9 / 37$ \\
\hline Mycophenylate & $\begin{array}{l}\text { (SARS-CoV-2 or coronavirus or COVID or betacoronavirus or MERS-CoV or } \\
\text { SARS-CoV) AND (mycophenolate mofetil OR mycophenolate OR myfortic) }\end{array}$ & $13 / 29$ \\
\hline Tacrolimus & $\begin{array}{l}\text { (SARS-CoV-2 or coronavirus or COVID or betacoronavirus or MERS-CoV or } \\
\text { SARS-CoV) AND (envarsus or tacni or tacrolimus or prograf or FK506) }\end{array}$ & $3 / 18$ \\
\hline Anti-CD20 & $\begin{array}{l}\text { ((SARS-CoV-2 or coronavirus or COVID or betacoronavirus or MERS-CoV or } \\
\text { SARS-CoV) AND (anti-cd } 20 \text { monoclonal antibodies or anti-cd } 20 \text { or rituximab } \\
\text { or truxima or zevalin or ruxience or rituxan or arzerra or gazyva) }\end{array}$ & 0 \\
\hline CTLA4-Ig & $\begin{array}{l}\text { ((SARS-CoV-2 or coronavirus or COVID or betacoronavirus or MERS-CoV or } \\
\text { SARS-CoV) AND (CTLA-4 Ig or CTLA4 or CTLA- } 4 \text { or Ipilimumab or yervoy) }\end{array}$ & 0 \\
\hline
\end{tabular}

\section{Results}

\section{All cytotoxic chemotherapy}

Cytotoxic chemotherapy inhibits cell division through multiple mechanisms. It may have therapeutic activity as compounds against corona viral strains. Moreover, cancer patients who have undergone chemotherapy may be at increased risk of developing symptoms of SARS.

\section{Results}

The search yielded 24 results, of which 18 were included (Supplementary Table 1). Below are key case-reports of interest to highlight:

- Coronavirus was one of the most common viral pathogens identified in paediatric cancer patients undergoing chemotherapy, second to human rhinovirus [4]. Viral co-detection was frequent in patients with cancer and acute respiratory infections.

- A brain biopsy was HCoV-OC43-positive by metagenomic next-generation sequencing in the case of a 1-year-old child with pre-B acute lymphoblastic leukaemia [5].

- A case of a young woman with stage IIIA breast cancer from 1999 reported that diagnosis of coronavirus following treatment for 
cancer using a high-dose chemotherapy regimen and autologous bone marrow and stem cell transplantation. The electron microscopy revealed coronavirus pneumonia [6]. Coronavirus should be potentially considered in the differential diagnoses of respiratory failure in patients who have undergone high-dose chemotherapy and autologous bone marrow transplantation.

In addition, some further observations have been made in relation to specific treatments:

- Although HIV protease inhibitors such as lopinavir has been suggested as a low-micromolar inhibitor of MERS-CoV, the different mechanistic classes that HIV and coronavirus fall under meant that there was low affinity for coronavirus strains compared to HIV [7].

- The following compounds have been shown to be active in vitro against the SARS-CoV virus: TNFa-converting enzyme inhibitor (TAPI2); IFN-a (B/D, mDEF201 by adenovirus 5 vector, CR3014 humanized monoclonal antibody (a neutralising antibody specific for SARS$\mathrm{CoV}$ ), recombinant IFN- $\mathrm{a} 2 \mathrm{~b}$ and type I IFN- $\beta$ ); Interferon inducers (Ampligen and polyinosinic-polycytidylic); therapeutic antibodies (2978/10, equine anti-SARS-CoV F[ab'] and monoclonal antibody 201); attachment inhibitors (Urtica Dioica lectin and griffithsin); host immune system [8].

- 6-mercaptopurine (6MP) and 6-thioguanine (6TG) have been used in cancer chemotherapy for treatment of acute lymphoblastic or myeloblastic leukaemia and were found to be specific inhibitors for the SARS coronavirus [9].

- Carbohydrate-binding agents (CBA) may be able to block enveloped viruses other than HIV in their entry process and coronaviruses and influenza viruses are other examples of enveloped viruses that may be highly susceptible to the antiviral action of CBAs [10].

- The genome of SARS-CoV encodes five major proteins: the spike protein (S), the envelope protein (E), the membrane glycoprotein (M), and the nucleocapsid protein (N). M and $\mathrm{E}$ may help host cells to induce the production of protective IFN- $a$ to fight against the virus. Bananin 1-[3-hydroxy-5-(hydroxymethyl)-2-methyl-4-pyridinyl]-2,8,9-trioxaadamantane-3,5,7-triol acts as zinc $\left(\mathrm{Zn}^{2+}\right)$ chelator and is therefore of interest to target and inhibit immunodeficiency virus type 1 (HIV-1) zinc finger HIV-1 RNA-binding nucleocapsid protein p7 (NCp7). Bananin is converted to bananin 5'-monophosphate (BNP) which together with B6RA (vitamin A-vitamin B6 conjugate) and could inhibit infectious virion encapsidation. Targets of BNP and B6RA has shown to be present also in SARS-associated coronavirus making them possible therapeutic candidates [11].

\section{Conclusion}

Coronavirus strains were one of the most common viral pathogens identified in paediatric cancer patients undergoing chemotherapy. Patients with pre-B acute lymphoblastic leukaemia and breast cancer who have undergone chemotherapy have reported cases of coronavirus infection. Cytotoxic therapies used in cancer chemotherapy such as 6MP and 6TG have shown to be specific inhibitors for SARS coronavirus in in vitro studies. However, further in vitro and in vivo studies are required to confirm this, especially in COVID-19. Currently, there is no scientific evidence of the interaction between methotrexate and COVID-19.

\section{Low-dose steroids and NSAIDs}

Since the outbreak of the novel COVID-19 infection, various contradictory information has been circulated regarding the potentially negative effect of treating patients with NSAIDs, non-NSAIDs and corticosteroids. NSAIDs work through inhibition of the cyclooxygenase enzymes (COX-1/COX-2), which are involved in the synthesis of key biological mediators. These mediators in turn control inflammation. Corticosteroids are involved in a number of key physiological processes including the immune response and inflammation and low-dose steroids are often prescribed to cancer patients with suppressed immune systems to prevent the development of related auto-immune diseases.

\section{Results}

A total of 58 studies were identified from the search terms, of which 13 were deemed suitable for inclusion (Supplementary Table 2). Our search did not identify any strong evidence for or against the use of ibuprofen for treatment of COVID-19 specifically. One study did however link SARS-CoV to the downregulation of angiotensin converting enzyme-2 (ACE2) which is upregulated by ibuprofen [12]. The authors of this study were investigating the link between the severity of COVID-19 symptoms in patients with asthma and hypertension. 
The only other study to investigate a non-steroidal anti-inflammatory drug was one which looked at indomethacin [13]. This study suggested that indomethacin exhibited potent antiviral activity against canine coronavirus (dramatically inhibiting virus replication and protecting the host cell from virus-induced damage). This activity was also observed against human SARS-CoV at a concentration dose of $1 \mathrm{mg} / \mathrm{kg}$.

In general, there appeared to be a few positive results for the use of corticosteroids in viral infections such as SARS-CoV [14-19]. Corticosteroids were widely used during the SARS-CoV outbreak due to their known ability to modulate a variety of involved cytokines (including IL-1, IL-6, IL-8, IL-12 and TNFa) [14, 16]. Various studies in humans noted that corticosteroids appeared effective in reducing immunopathological damage but concerns centred around the promotion of viral rebound and association with adverse events (including acute respiratory distress syndrome) [14]. One laboratory study which treated porcine respiratory coronavirus infected pigs with dexamethasone suggested that one or two doses of the corticosteroid in the acute phase of infection may effectively alleviate early pro-inflammatory response, but prolonged administration may play a role in enhancing viral replication [18]. A separate Chinese study, which separated SARS-CoV patients into 4 treatment groups, identified early high-dose steroids in combination with a quinolone as producing the best patient outcomes [19]. Nevertheless, one review stated that the WHO does not currently recommend corticosteroids in other viral diseases such as Dengue as the 'glucocorticoid-mediated stimulation of the hypothalamic-pituitaryadrenal axis can also drive lymphocytopenia, or it may promote exaggerated pro-inflammatory responses that eventually cause a worsening of the pathogenic condition' [20].

\section{Conclusion}

The current literature does not give conclusive evidence for or against the use of NSAIDs in the treatment of COVID-19 patients, though there appears to be some evidence that corticosteroids may be beneficial in the treatment of SARS-CoV. However, it is important to note this is not specific to COVID-19.

\section{TNFa blocker}

TNF family of receptors and cytokines is very large and are often the targets for drugs. One example are TNFa inhibitors, which act by supressing the physiologic response to TNFa. TNFa is a pro-inflammatory cytokine involved in autoimmune and immune-mediated disorders such as rheumatoid arthritis, ankylosing spondylitis, inflammatory bowel disease, psoriasis, hidradenitis suppurativa and refractory asthma. Inhibitors of TNFa may be used in their treatment.

Inhibition of TNFa can be achieved with a monoclonal antibody, such as infliximab (Remicade), adalimumab (Humira), certolizumab pegol (Cimzia) and golimumab (Simponi), or with the receptor fusion protein etanercept (Enbrel).

\section{Results}

A total of three studies were identified, of which two were deemed suitable for inclusion (Supplementary Table 3). The first study was a research letter that suggested that TNFa has been implicated in the severe immune-based pulmonary injury caused by SARS coronavirus, suggesting that TNFa inhibitors could be a potential treatment for the acute respiratory disease syndrome caused by coronavirus [21]

The second study utilised 22 piglets to assess the efficacy of an anti-TNFa)therapy for endotoxin respiratory diseases and observed that TNFa blockade was not associated with decrease in disease severity [22].

\section{Conclusion}

Currently, there is no evidence indicating that TNFa blockade is harmful to patients in the context of COVID-19.

\section{IL-6 blockade}

IL-6, promptly and transiently produced in response to infections and tissue injuries, contributes to host defence through the stimulation of acute phase responses, hematopoiesis, and immune reactions. Although its expression is strictly controlled by transcriptional and posttran- 
scriptional mechanisms, dysregulated continual synthesis of IL-6 plays a pathological effect on chronic inflammation and autoimmunity [23]. For this reason, tocilizumab, a humanized anti-IL-6 receptor antibody was developed. Other approved anti IL-6 drugs are siltuximab (Sylvant) and sarilumab. Several agents are in clinical trials:olokizumab (CDP6038), elsilimomab, BMS945429(ALD518), sirukumab (CNTO 136), CPSI2364, ALX-0061, clazakizumab, olokizumab, sarilumab, sirukumab, ARGX-109, FE301 and FM101.

\section{Results}

A total of 108 studies were identified from the second search strategy, 23 were suitable for inclusion (Supplementary Table 4). The first search strategy found no hits.

\section{IL6 an actor in the pathogenetic mechanisms of the coronavirus infection}

- COVID-19 induces a pro-inflammatory generation and secretion of cytokines including IL-1b and IL-6 via the toll like receptors (TLR) that causes the production of active mature IL-1b which is a mediator of lung inflammation, fever and fibrosis. Anti-inflammatory cytokines, such as IL1-Ra, IL-37 or IL-38 could potentially provide relief in both systemic inflammation and fever occurring after infection [24].

- Cytokine profiles in patients diagnosed with SARS showed marked elevation of T-helper lymphocyte type 1 (Th1) cytokine interferongamma (IFN- $\gamma$ ), inflammatory cytokines IL-1 $\beta$, IL-6 and IL-12 for at least two weeks after disease onset. Children however presented a much milder cytokine and chemokine storm [16].

- The high levels of IL-6 in the acute stage associated with lung lesions found in SARS patients are activated by the viral nucleocapsid SARS-CoV N protein [25].

- Over induction of inflammatory cytokine and dysregulation of cytokine signalling has been observed in patients with SARS in comparison with other respiratory viruses including respiratory syncytial virus (RSV), influenza A virus (FluAV), and human parainfluenza virus type 2 (hPIV2). SARS-CoV and RSV induced high levels of IL-6 and RANTES compared with FluAV and hPIV2 [26].

- The N-protein of SARS-CoV induces pulmonary inflammatory reaction and acute lung injury, which were related to the increase and imbalance of pro-inflammatory and anti-inflammatory cytokines. Glucocorticoids could effectively alleviate the pulmonary inflammatory reaction induced by N-protein of SARS-CoV [15].

- SARS-CoV does not productively infect human macrophages (Mphi) or dentritic cells (DCs), however it modulates a massive release of IL- 6 and IL-12 and compromises the endocytic capacity (e.g., antigen capture capture) of Mphi was significantly compromised [27].

- Changes in plasma T helper (Th) cell cytokines, inflammatory cytokines and chemokines in 20 patients diagnosed with SARS were assessed. The elevation of Th1 cytokine IFN- $\gamma$, inflammatory cytokines IL-1, IL- 6 and IL-12 and chemokines IL-8, MCP-1 and IP-10 confirmed the activation of Th1 cell-mediated immunity and hyper-innate inflammatory response in SARS through the accumulation of monocytes/macrophages and neutrophils [17].

\section{IL-6 as a potential marker of disease severity in coronavirus infected patients}

- IL-6 blood measurements seem useful to diagnose severe COVID-19 cases. The findings suggest that IL-6 and D-Dimer level can be used to estimate the severity of COVID-19. The optimum critical point of IL-6 in the group was $24.3 \mathrm{pg} / \mathrm{ml}$, which was the upper limit of no severe pneumonia [28].

- The increased expression of IL-2R and IL-6 in serum is expected to predict the severity of the 2019-nCoV pneumonia and the prognosis of patients [29].

- The serum levels of IL-6 and CXCL-10 were significantly elevated in MERS-CoV patients who developed severe diseases [30].

- A new lethal animal model was characterised for SARS-CoV. Strain v2163 had nine mutations that increased levels of IL-1alpha and IL-6 in mice. The high IL-6 expression was correlated with mortality [31].

- SARS vaccination was tested in a murine SARS model. A high level of IL-6 and on days 2 and 3 after SARS-CoV infection was closely linked to the virus replication and disease severity [32]

- Interleukin-6 (IL-6) and IL-8 are key SARS-CoV-induced epithelial cytokines capable of inhibiting the T-cell-priming ability of dendritic cells, a cellular element of the host innate defenses against respiratory infections, leading to an exacerbated inflammatory cascades and severe tissue damage in SARS patients [33]. 
- In patients with a diagnosis of SARS-associated coronavirus infection, there were no significant differences in peak levels of IL-6, IL-8 and TNFa between patients with and without acute respiratory distress syndrome. However, CRP and TNFa were associated with worse outcomes and might be used as prognostic markers of SARS [34].

- IFN-gamma, IL-18, TGF-beta, IL-6, IP-10, MCP-1, MIG were highly elevated in the acute phase sera of Taiwan SARS patients, being IL-18, IP-10, MIG, and MCP-1 were significantly higher in the death group than in the survival group. It suggests that an interferongamma-related cytokine storm was induced post SARS coronavirus infection [35].

- Eight patients with SARS [36] were treated with ribavirin, which was not effective in reducing the SARS coronavirus load in three of eight. Elevated levels of interleukin (IL)-6 and IL-8 subsequent to the peak viral load were found in eight and six cases [37].

- A cytokine profiling was performed for 110 serum from healthy donors, patients with SARS, patients with severe SARS, and patients with SARS in convalescence. IL6 concentrations were significantly elevated in severe SARS patients, but the IL-6 concentrations were similar in convalescent patients and control subjects which suggested that IL6 is associated with SARS severity [38].

- The authors of this study set out to study the inflammatory cytokine profile in children with SARS. They found that the plasma concentrations' key proinflammatory cytokines, including IL-6, were not substantially increased in any of the patients throughout the course of illness. From this, the authors stated that the cytokine results cast doubt on the liberal use of corticosteroids in paediatric SARS patients [39].

\section{Potential targets for therapeutic intervention related to IL6 regulation during infection}

- ADAM-17 regulates IL-6 class switching as a mediator between pro- and anti-inflammatory responses to viral antigenic stimuli in Ebola, SARS-CoV and dengue infections in humans. Therefore, ADAM-17 should be considered as a potential target molecule for novel antiviral drug discovery for infections, such as SARS-CoV [20]

- SARS-CoV sSRNA is a new therapeutic target given its capacity to cause acute lung injury in mice with a high mortality rate in vivo experiment suggesting that SARS-CoV specific GU-rich ssRNA plays a very important role in the cytokine storm associated with a dysregulation of the innate immunity [40].

- DUSP1 and p38 MAPK are potential therapeutic targets for coronavirus infectious bronchitis virus, given their capability to reduce the production of an excessive amount of IL-6 and IL-8 in the infected cells [41].

\section{Potential therapeutic agents that inhibit the infection-induced production of IL6}

- Pretreatment of primary cultures of human nasal and tracheal epithelial cells with glycopyrronium or formoterol decreased viral RNA levels and/or titers, the expression of the HCoV-229E and the infection-induced production of cytokines, including IL-6, IL-8 and IFNbeta. Treatment of the cells with the CD13 inhibitor 2'2'-dipyridyl decreased viral titers. Pretreatment of the cells with a combination of three drugs (glycopyrronium, formoterol and budesonide) exerted additive inhibitory effects on viral titers and cytokine production [42].

\section{Conclusion}

It has been suggested that the pathogenesis of SARS-CoV is mediated by disproportional immune responses and the ability of the virus to circumvent innate immunity. The COVID-19 infection has also been observed to induce pro-inflammatory cytokine generation and secretion of cytokines, such as IL-6, which dysregulates the local inflammatory responses that have been suggested as partially responsible for the devastating acute respiratory distress syndrome.

Moreover, it has been observed that COVID-19 induces high levels of IL-6 for at least 2 weeks after disease onset. Children presented lower levels of cytokine production. IL-6 has been suggested as a potential prognostic marker of COVID-19 disease severity. Different molecules related with the IL6 pathway have been suggested as potential therapeutic targets such as ADAM-17, SARS-CoV ssRNA, DUSP1 and p38 MAPK.

Currently, there is no scientific evidence of the beneficial impact of IL-6 inhibitors in the modulation of the COVID-19 infection. Further understanding of the role of IL-6 reduction will be forthcoming as the pandemic progresses and further clinical data becomes available. In 
vitro treatment with glycopyrronium, formoterol and budesonide exerted additive inhibitory effects on viral titers and cytokine production human nasal and tracheal epithelial cells.

\section{JAK inhibitors}

JAK inhibitors work by inhibiting the activity of one or more of the JAK family of enzymes, including, JAK1, JAK2, JAK3 and TYK3. JAKs interact with signal transducer and activator of transcription proteins (STATs) and the JAK-STAT pathway is central to cellular response to exogenous signals in the immune system. The JAK family of enzymes are responsible for signal transduction and JAK inhibitors play a major role in inhibiting and blocking cytokine release that can contribute to growth of malignant cells in cancer. JAK inhibitors are used in the treatment of cancer and inflammatory diseases such as rheumatoid arthritis [43].

This review focuses on how the JAK-STAT pathway can be manipulated to reduce viral entry and inflammation in patients with coronavirus. The main targets that the review highlighted were baricitinib (JAK inhibitor), IRE1a (an endoplasmic reticulum stress sensor, leading to an increased expression of negative regulators of JAK-STAT SOCS1 and SOCS3) and combination therapies using tylophorine-based compounds with JAK2 inhibitors.

\section{Results}

Fifteen studies were yielded from the search of which 4 were deemed suitable for inclusion (Supplementary Table 5).

\section{Baricitinib}

Baricitinib (Olumiant) is a JAK inhibitor that was approved by the European Medicines Agency in February 2017 for the treatment of moderate-to-severe active rheumatoid arthritis in adults with an inadequate response to one or more disease-modifying anti-rheumatic drugs [44]. One study suggested the use of Baricitinib to reduce the viral entry and inflammation caused by 2019-nCoV. Most viruses enter cells through receptor-mediated endocytosis. ACE2, a cell-surface protein expressed on cells in the kidney, blood vessels, heart, and alveola type 2 (AT2) cells in the pulmonary epithelia, may be the receptor that 2019-nCoV uses to infect lung cells. The authors of Richardson et al [45] suggest that by inhibiting adaptor associated protein kinase 1 (AAK1) receptor that promotes endocytosis involved in ACE2, Baricitinib may reduce both the viral entry and the inflammation in 2019-nCoV patients.

\section{IRE1a}

Inositol-requiring transmembrane kinase/endoribonuclease $1 a$ (IRE1a) is an endoplasmic reticulum stress sensor that leads to increased expression of negative regulators of JAK-STAT, suppressor of cytokine signalling (SOCS)-1 and SOCS-3 [46]. Therefore, IRE1 a may be a novel target against coronavirus infection requiring further exploration.

\section{Tylophorine-based compounds}

Tylophorine-based compounds are isolated from plants and exert potent anti-coronaviral activities against SARS-CoV and MERS-CoV [47]. Nuclear factor kappa-light-chain-enhancer of activated B cells (NF-KB) activation is a common pro-inflammatory response of host cells to viral infection. Following in vitro analysis, Yang et al [48] suggests the use of a combination therapy for SARS-CoV or MERS-CoV, wherein a tylophorine compound known to target transmissible gastroenteritis virus and a JAK2 inhibitor synergise to block the alternative dominant NF-KB activation mediated by JAK2. Therefore, the combination treatment for the inhibition of coronavirus per se, e.g. viral genome replication, and blocking cellular NF-kB activation by coronaviruses, is a promising approach for the development of anti-coronavirals.

\section{Conclusion}

Current studies suggest that although there are potential targets in the JAK-STAT pathway that can be manipulated in the treatment for coronaviruses, they are all in early stages and require further in vitro and in vivo studies to confirm their therapeutic effects. 


\section{IL-1 blockade}

IL-1 is a pro-inflammatory cytokine and an important mediator of local and systemic inflammation. Excessive IL-1 release during viral infections can cause lung and tissue inflammation, fever and fibrosis. IL-1 suppression has found to be effective in many inflammatory diseases including rheumatoid arthritis [24].

It is well established that an over-expression of interleukin-1 is a hallmark of SARS-CoV infection, probably through activation of transcription factor nuclear factor, activator protein 1 and activating factor 2. In COVID-19 specifically, the virus is thought to bind to TLRs which activate the formation of pro-IL-1 and activation of the inflammasome [24]. This inflammasome activation is important for the regulation of cells of both the innate and adaptive immune system paving the way for specific immune responses. As part of the inflammasome activation, IL1-b is subsequently produced which mediates the inflammation of the lungs, fever and fibrosis thus causing respiratory complications in the infected host.

\section{Results}

A total of 37 studies were identified from the search of which 9 were deemed suitable for inclusion (Supplementary Table 6). Many of the studies were in vitro studies and repeatedly demonstrated increased IL-1 levels in patients infected with a coronavirus. One study investigated the levels of various inflammatory cytokines in 29, COVID-19 patients in China and compared the levels between general, severe and critically ill groups [49]. The authors reported no significant differences in IL-1b levels between the three groups of patients. Another study involving 20 consecutive SARS patients admitted to a Hong Kong hospital identified significantly elevated levels of IL-1 $\beta$ within the first 12 , 7 and 5 days following onset of infection [17]. Those patients with more severe disease were treated with pulsed methylprednisolone and IL-1 $\beta$ levels returned to normal after 7 days. The seven patients with less severe disease did not receive any dosage of corticosteroids and their cytokine levels returned to normal range levels over the same 7-day time period.

A further Chinese study also identified reduced levels of IL-1 $\beta$ following administration of corticosteroids- suggesting inhibition of proinflammatory cytokines such as IL-1 may be a beneficial treatment strategy for treatment of SARS [50]. A third study, which measured serum cytokine levels in four patient groups including controls, patients with SARS, patients with severe SARS and convalescent SARS patients suggested that longer term treatment (over a period of 7-10 days) with low-dose steroids can alter serum cytokine levels, including IL-1a [38].

One rat model showed promising results for an IL-1 receptor antagonist which reduced the chemokine expression in infected animals [51]. However, this result cannot be generalised for humans. Unfortunately, one study, in which the authors state the 'demonstrate for the first time that inflammation by coronavirus may be inhibited by anti-inflammatory cytokines belonging to the IL-1 family', was only available as an abstract [52]. Therefore, further evidence or information to back this claim up is not available.

\section{Conclusion}

Overall, this review demonstrated that although it is evident that IL-1 is elevated in patients infected with a coronavirus, there is not at present evidence for an established role for IL-1 blockers in the treatment of COVID-19 in humans. The literature did, however, suggest a potential role for low-dose corticosteroids to reduce levels of pro-inflammatory markers, such as IL-1, which are elevated as part of the immune response and may have a role in the severe lung damage associated with human coronaviruses.

\section{Mycophenolate}

Mycophenolate mofetil (which is a derivative of mycophenolic acid (MPA)) is an immune suppressant, antineoplastic and antiviral mediation. According to the British National Formulary, mycophenolate mofetil is used for the prophylaxis of acute rejection in renal transplantation and is usually used in combination with a corticosteroid and ciclosporin. 


\section{Results}

Almost all of the studies investigated MPA as a potential therapy for MERS-CoV due to its anti-viral properties. Six of the 13 selected studies were in vitro studies, two were in vivo, one was a clinical example and four were reviews (therefore there was some overlapping of results) (Supplementary Table 7).

\section{In-vitro studies}

In general, the in vitro studies looked positive with MPA targeting the papain like proteases of both MERS-CoV and SARS-CoV [53, 54]. The studies found that MPA showed strong inhibition of the virus with a very low IC50 [55-57].

\section{In vivo study}

MPA can been used in combination with interferon-beta (IFN-b). One study, which applied this regime in marmosets exhibiting a severe disease resembling human MERS, reported high viral loads with more severe or even fatal disease [28]. The authors of this study state that MPA is likely to cause more harm than benefit to MERS patients.

\section{Clinical studies}

According to the review by Mo and Fisher [58], MPA monotherapy had not been tested in a clinical setting for the treatment of MERS-CoV. Al Ghamdi et al [59], presented an example where eight patients were treated with MPA for MERS-CoV, seven in combination with IFN- $\beta$.

All eight of these patients survived, however the review by Mo and Fisher stated that this group of patients had lower Acute Physiology and Chronic Health Evaluation II scores compared with others in the cohort who received a variety of antiviral agents including ribavirin and IFNa, steroids and antibiotics. Therefore, the results must be interpreted with caution.

\section{Conclusion}

Whilst the in vitro studies showed promising results for MPA against MERS, the in vivo studies suggest that its use is likely to cause more harm than benefit and hence is not likely to be useful against coronavirus infections. The clinical studies are too small to confirm or deny any beneficial use for MERS-CoV patients.

\section{Tacrolimus}

Tacroliumus, also known as fujimycin, envarsus or FK506, is an immunosuppressive drug which is mainly administered after allogeneic organ transplant to lower risk of organ rejection. It's mechanism of action focusses on inhibition of calcineurin which is involved in the production of IL-2. IL-2 is a cytokine which promotes the development and proliferation of T cells which form a vital component of the human adaptive immune response.

\section{Results}

A total of 18 studies were identified from the search terms, of which three were deemed suitable for inclusion (Supplementary Table 8).

Overall, the literature appeared to suggest a potential role for tacrolimus in the treatment of human coronaviruses. In a case study of two renal transplant recipients who tested positive for MERS CoV, a patient who was being treated with an immunosuppressive regimen of tacrolimus underwent full recovery whilst the other patient (who was not on this treatment regimen) succumbed to the infection [60]. The patient who eventually made a full recovery was also treated with antibacterial therapy and a reduced dose of mycophenolate mofetil and it is therefore not possible to conclude that patient recovery due to tacrolimus.

The two other included studies were both laboratory studies involving cell line culture. The first investigated pathways of coronavirus viral replication as potential antiviral therapeutic targets [61]. Genome-wide SARS-CoV yeast-two-hybrid interaction screen with human cDNA 
libraries identified FK506-binding proteins as interaction partners of SARS-CoV non-structural protein 1. Subsequently, the authors investigated whether tacrolimus inhibits viral replication of human coronaviruses. VeroFM cells infected with SARS-CoV and other human coronaviruses were treated with FK506. Results showed that FK506 effectively inhibited viral replication of SARS-CoV, HCoV-NL63 and HCoV-229E at non-toxic, low-micromolar concentrations with a reduction in viral titers to undetectable levels. The second study further confirmed this inhibition using novel non-immunosuppressive derivatives of FK506 in the context of HCoV-NL63 at low-micromolar, non-cytotoxic concentrations in cell culture [62].

\section{Conclusion}

Overall the small amount of literature available suggests a potential role of FK506 (tacrolimus) as a potent antiviral in the treatment of human coronaviruses. It is important to note, however, that COVID-19 is a novel disease and may have different aetiology and mechanistic action compared to existing strains and to date, this immunosuppressive drug and its derivatives has not been tested in humans. Further study is warranted, both in the clinical setting and laboratory.

\section{Anti-CD20}

No studies were identified for inclusion.

\section{CTLA-4 Ig}

No studies were identified for inclusion.

\section{Overall conclusion}

The rapidly progressing SARS-CoV-2 pandemic has led to challenging decision-making about the treatment of critically unwell patients with the novel viral infection. In parallel, doctors across multiple specialties are making clinical decisions about the appropriate continuation of treatments for patients with chronic illnesses requiring immune-suppressive medication. This systematic review looks to provide guidance from the current available literature.

As the COVID-19 pandemic progresses, collective effort to capture data from prospective trials is required. Sponsors of randomized controlled trials recruiting patients randomized to receive immune modulatory drugs that may be affected by COVID-19 should collect data about the disease outcomes and consider interim analysis of potential advantages and disadvantages associated with using one of these medications.

Low-dose prednisolone and tacrolimus therapy may have beneficial impacts on the course of SARS-CoV-2. This observation requires further validation. The mycophenolate mofetil picture is less clear, with conflicting data from pre-clinical studies. There is no definitive evidence that specific cytotoxic drugs, low-dose methotrexate for auto-immune disease, NSAIDs, JAK kinase inhibitors or anti-TNFa biological agents are contraindicated. There is evidence that IL-6 peak levels are associated with severity of pulmonary complications. Ongoing studies of blockade of the IL-6 pathway are rational and will hopefully inform practice as the pandemic progresses.

\section{Funding declaration}

We would like to thank our various funders: Guy's and St Thomas' Charity, Cancer Research UK (C45074/A26553), and the CRUK King's Health Partner Centre.

\section{Conflicts of interest}

The authors have no conflicts of interest to declare. 


\section{References}

1. Chen N, Zhou M, and Dong X, et al (2020) Epidemiological and clinical characteristics of 99 cases of 2019 novel coronavirus pneumonia in Wuhan, China: a descriptive study Lancet 395(10223) 507-513 https://doi.org/10.1016/S0140-6736(20)30211-7 PMID: 32007143

2. Wang H and Zhang L (2020) Risk of COVID-19 for patients with cancer Lancet Oncol https://doi.org/10.1016/S1470-2045(20)30149-2

3. Xia Y, Jin R, and Zhao J, et al (2020) Risk of COVID-19 for cancer patients Lancet Oncol https://doi.org/10.1016/S1470-2045(20)30150-9 PMID: 32142622

4. Benites EC, Cabrini DP, and Silva AC, et al (2014) Acute respiratory viral infections in pediatric cancer patients undergoing chemotherapy J Pediatr (Rio J) 90(4) 370-376 https://doi.org/10.1016/j.jped.2014.01.006

5. Nilsson A, Edner N, and Albert J, et al (2020) Fatal encephalitis associated with coronavirus OC43 in an immunocompromised child Infect Dis (Lond) 1-4

6. Folz RJ and Elkordy MA (1999) Coronavirus pneumonia following autologous bone marrow transplantation for breast cancer Chest 115(3) 901-905 https://doi.org/10.1378/chest.115.3.901 PMID: 10084516

7. LaFemina RL (2014) Alternative screening approaches for discovery of middle east respiratory syndrome coronavirus inhibitors Antimicrob Agents Chemother 58(8) 4251 https://doi.org/10.1128/AAC.03406-14 PMID: 24867994 PMCID: 4135998

8. Barnard DL and Kumaki Y (2011) Recent developments in anti-severe acute respiratory syndrome coronavirus chemotherapy Future Virol 6(5) 615-631 https://doi.org/10.2217/fvl.11.33 PMID: 21765859 PMCID: 3136164

9. Chen X, Chou CY, and Chang GG (2009) Thiopurine analogue inhibitors of severe acute respiratory syndrome-coronavirus papain-like protease, a deubiquitinating and delSGylating enzyme Antivir Chem Chemother 19(4) 151-156 https://doi. org/10.1177/095632020901900402 PMID: 19374142

10. Balzarini J (2007) Carbohydrate-binding agents: a potential future cornerstone for the chemotherapy of enveloped viruses? Antivir Chem Chemother 18(1) 1-11 https://doi.org/10.1177/095632020701800101 PMID: 17354647

11. Kesel AJ (2003) A system of protein target sequences for anti-RNA-viral chemotherapy by a vitamin B6-derived zinc-chelating trioxaadamantane-triol Bioorg Med Chem 11(21) 4599-4613 https://doi.org/10.1016/S0968-0896(03)00500-5 PMID: 14527557

12. Fang L, Karakiulakis G, and Roth M (2020) Are patients with hypertension and diabetes mellitus at increased risk for COVID-19 infection? Lancet Respir Med https://doi.org/10.1016/S2213-2600(20)30116-8 PMID: 32171062

13. Amici C, Di Caro A, and Ciucci A, et al (2006) Indomethacin has a potent antiviral activity against SARS coronavirus Antivir therapy 11(8) 1021-1030

14. Chihrin S and Loutfy MR (2005) Overview of antiviral and anti-inflammatory treatment for severe acute respiratory syndrome Expert Rev Anti Infect Ther 3(2) 251-262 https://doi.org/10.1586/14787210.3.2.251 PMID: 15918782

15. Hao D, He L-X, and Qu J-M, et al (2005) [A study of pulmonary inflammatory reaction induced by N-protein of SARS-CoV in rat models and effects of glucocorticoids on it] Zhonghua nei ke za zhi 44(12) 890-893

16. Lam CWK, Chan MHM, and Wong CK (2004) Severe acute respiratory syndrome: clinical and laboratory manifestations Clin Biochem $\operatorname{Rev} 25(2)$ 121-132

17. Wong CK, Lam CWK, and Wu AKL, et al (2004) Plasma inflammatory cytokines and chemokines in severe acute respiratory syndrome Clin Exp Immunol 136(1) 95-103 https://doi.org/10.1111/j.1365-2249.2004.02415.x PMID: 15030519 PMCID: 1808997 
18. Zhang $\mathrm{X}$, Alekseev K, and Jung K, et al (2008) Cytokine responses in porcine respiratory coronavirus-infected pigs treated with corticosteroids as a model for severe acute respiratory syndrome J Virol 82(9) 4420-4428 https://doi.org/10.1128/JVI.02190-07 PMID: 18287230 PMCID: 2293053

19. Zhao Z, Zhang F, and Xu M, et al (2003) Description and clinical treatment of an early outbreak of severe acute respiratory syndrome (SARS) in Guangzhou, PR China J Med Microbiol 52(Pt 8) 715-720 https://doi.org/10.1099/jmm.0.05320-0 PMID: 12867568

20. Mahmud-Al-Rafat A, Majumder A, and Taufiqur Rahman KM, et al (2019) Decoding the enigma of antiviral crisis: does one target molecule regulate all? Cytokine Cytokine 115 13-23 https://doi.org/10.1016/j.cyto.2018.12.008 PMID: 30616034

21. Tobinick E (2004) TNF-alpha inhibition for potential therapeutic modulation of SARS coronavirus infection Curr Med Res Opin 20(1) 39-40 https://doi.org/10.1185/030079903125002757 PMID: 14741070

22. Atanasova K, Van Gucht S, and Van Reeth K (2010) Anti-TNF-alpha therapy does not ameliorate disease in a model of acute virus-endotoxin mediated respiratory disease in pigs Vet Immunol Immunopathol 137(1-2) 12-9 https://doi.org/10.1016/j.vetimm.2010.04.003 PMID: 20466438 PMCID: 2922464

23. Tanaka T, Narazaki M, and Kishimoto T (2014) IL-6 in inflammation, immunity, and disease Cold Spring Harb Perspect Biol 6(10) a016295 https://doi.org/10.1101/cshperspect.a016295 PMID: 25190079 PMCID: 4176007

24. Conti P, Ronconi G, and Caraffa A, et al (2020) Induction of pro-inflammatory cytokines (IL-1 and IL-6) and lung inflammation by COVID-19: anti-inflammatory strategies J Biol Regul Homeost Agents 34(2) pii:1 PMID: 32171193

25. Zhang X, Wu K, and Wang D, et al (2007) Nucleocapsid protein of SARS-CoV activates interleukin-6 expression through cellular transcription factor NF-kappaB Virology 365(2) 324-335 https://doi.org/10.1016/j.virol.2007.04.009 PMID: 17490702

26. Okabayashi T, Kariwa H, and Yokota S-I, et al (2006) Cytokine regulation in SARS coronavirus infection compared to other respiratory virus infections J Med Virol 78(4) 417-424 https://doi.org/10.1002/jmv.20556 PMID: 16482545

27. Tseng C-TK, Perrone LA, and Zhu H, et al (2005) Severe acute respiratory syndrome and the innate immune responses: modulation of effector cell function without productive infection J Immunol 174(12) 7977-7985 https://doi.org/10.4049/jimmunol.174.12.7977 PMID: 15944304

28. Chan JF, Yao Y, and Yeung ML, et al (2015) Treatment with lopinavir/ritonavir or interferon-beta1b improves outcome of MERS-CoV infection in a nonhuman primate model of common marmoset J Infect Dis 212(12) 1904-1913 https://doi.org/10.1093/infdis/jiv392 PMID: 26198719

29. Chen L, Liu HG, and Liu W, et al (2020) [Analysis of clinical features of 29 patients with 2019 novel coronavirus pneumonia] Zhonghua jie he he hu xi za zhi = Zhonghua jiehe he huxi zazhi = Chin J Tuberc Respir Dis 43(3) 203-208

30. Kim ES, Choe PG, and Park WB, et al (2016) Clinical progression and cytokine profiles of middle east respiratory syndrome coronavirus infection J Korean Medi Sci 31(11) 1717-1725 https://doi.org/10.3346/jkms.2016.31.11.1717

31. Barnard DL, Day CW, and Bailey K, et al (2006) Enhancement of the infectivity of SARS-CoV in BALB/c mice by IMP dehydrogenase inhibitors, including ribavirin Antiviral Res 71(1) 53-63 https://doi.org/10.1016/j.antiviral.2006.03.001 PMID: 16621037

32. Ishii $\mathrm{K}$, Hasegawa $\mathrm{H}$, and Nagata $\mathrm{N}$, et al Neutralizing antibody against severe acute respiratory syndrome (SARS)-coronavirus spike is highly effective for the protection of mice in the murine SARS model Microbiol Immunol 53(2) 75-82 PMID: 19291090

33. Yoshikawa T, Hill T, and Li K, et al (2009) Severe acute respiratory syndrome (SARS) coronavirus-induced lung epithelial cytokines exacerbate SARS pathogenesis by modulating intrinsic functions of monocyte-derived macrophages and dendritic cells $J$ Virol 83(7) 3039-3048 https://doi.org/10.1128/JVI.01792-08 PMCID: 2655569

34. Sheng W-H, Chiang B-L, and Chang S-C, et al (2005) Clinical manifestations and inflammatory cytokine responses in patients with severe acute respiratory syndrome J Formosan Med Assoc = Taiwan yi zhi 104(10) 715-723 PMID: 16385373 
35. Huang K-J, Su I-J, and Theron M, et al (2005) An interferon-gamma-related cytokine storm in SARS patients J Med Virol 75(2) 185-194 https://doi.org/10.1002/jmv.20255

36. Wang C, Pang B-S, and National Research Project for Sars BG (2003) [Dynamic changes and the meanings of blood cytokines in severe acute respiratory syndrome] Zhonghua jie he he hu xi za zhi = Zhonghua jiehe he huxi zazhi = Chin J Tuberc Respir Dis 26(10) 586-589

37. Wang W-K, Chen S-Y, and Liu IJ, et al (2004) Temporal relationship of viral load, ribavirin, interleukin (IL)-6, IL-8, and clinical progression in patients with severe acute respiratory syndrome Clin Infect Dis 39(7) 1071-1075 https://doi.org/10.1086/423808 PMID: 15472864

38. Zhang Y, Li J, and Zhan Y, et al (2004) Analysis of serum cytokines in patients with severe acute respiratory syndrome Infect Immun 72(8) 4410-4415 https://doi.org/10.1128/IAI.72.8.4410-4415.2004 PMID: 15271897 PMCID: 470699

39. Ng PC, Lam CWK, and Li AM, et al (2004) Inflammatory cytokine profile in children with severe acute respiratory syndrome Pediatrics 113 e7-e14 https://doi.org/10.1542/peds.113.1.e7 PMID: 14702488

40. Li Y, Chen M, and Cao H, et al (2013) Extraordinary GU-rich single-strand RNA identified from SARS coronavirus contributes an excessive innate immune response Microb Infect 15(2) 88-95 https://doi.org/10.1016/j.micinf.2012.10.008

41. Liao $Y$, Wang $X$, and Huang M, et al (2011) Regulation of the p38 mitogen-activated protein kinase and dual-specificity phosphatase 1 feedback loop modulates the induction of interleukin 6 and 8 in cells infected with coronavirus infectious bronchitis virus Virology 420(2) 106-116 https://doi.org/10.1016/j.virol.2011.09.003 PMID: 21959016

42. Yamaya M, Nishimura H, and Deng X, et al (2020) Inhibitory effects of glycopyrronium, formoterol, and budesonide on coronavirus HCoV-229E replication and cytokine production by primary cultures of human nasal and tracheal epithelial cells Respir Investig https:// doi.org/10.1016/j.resinv.2019.12.005 PMID: 32094077

43. Kontzias A, Kotlyar A, and Laurence A, et al (2012) Jakinibs: a new class of kinase inhibitors in cancer and autoimmune disease Curr Opin Pharmacol 12(4) 464-470 https://doi.org/10.1016/j.coph.2012.06.008 PMID: 22819198 PMCID: 3419278

44. Agency EM (2019) Olumiant (baricitinib) [https://www.ema.europa.eu/en/medicines/human/EPAR/olumiant]

45. Richardson P, Griffin I, and Tucker C, et al (2020) Baricitinib as potential treatment for 2019-nCoV acute respiratory disease Lancet 395(10223) e30-e1 https://doi.org/10.1016/S0140-6736(20)30304-4 PMID: 32032529

46. Ma Y, Wang C, and Xue M, et al (2018) The coronavirus transmissible gastroenteritis virus evades the type I interferon response through IRE1alpha-mediated manipulation of the microRNA miR-30a-5p/SOCS1/3 axis J Virol 92(22) https://doi.org/10.1128/JVI.00728-18

47. Yang CW, Lee YZ, and Kang IJ, et al (2010) Identification of phenanthroindolizines and phenanthroquinolizidines as novel potent anticoronaviral agents for porcine enteropathogenic coronavirus transmissible gastroenteritis virus and human severe acute respiratory syndrome coronavirus Antivir Res 88(2) 160-168 https://doi.org/10.1016/j.antiviral.2010.08.009 PMID: 20727913

48. Yang C-W, Lee Y-Z, and Hsu H-Y, et al (2017) Targeting coronaviral replication and cellular JAK2 mediated dominant NF-кB activation for comprehensive and ultimate inhibition of coronaviral activity Sci Rep 7(1) 4105 https://doi.org/10.1038/s41598-017-04203-9 PMID: 28642467 PMCID: 5481340

49. Chen L, Liu HG, and Liu W, et al (2020) [Analysis of clinical features of 29 patients with 2019 novel coronavirus pneumonia] Zhonghua jie he he hu xi za zhi = Zhonghua jiehe he huxi zazhi $=$ Chin J Tuberc Respir Dis 43(0) E005

50. Zhu M (2004) SARS immunity and vaccination Cell Mol Immunol 1(3) 193-198

51. Miura TA, Wang J, and Holmes KV, et al (2007) Rat coronaviruses infect rat alveolar type I epithelial cells and induce expression of CXC chemokines Virology 369(2) 288-298 https://doi.org/10.1016/j.virol.2007.07.030 PMID: 17804032 PMCID: 2170429

52. Kritas SK, Ronconi G, and Caraffa A, et al (2020) Mast cells contribute to coronavirus-induced inflammation: new anti-inflammatory strategy J Biol Regul Homeost Agents 34(1) 
53. Lin MH, Moses DC, and Hsieh CH, et al (2018) Disulfiram can inhibit MERS and SARS coronavirus papain-like proteases via different modes Antiviral Res 150 155-163 https://doi.org/10.1016/j.antiviral.2017.12.015 PMID: 29289665

54. Cheng KW, Cheng SC, and Chen WY, et al (2015) Thiopurine analogs and mycophenolic acid synergistically inhibit the papain-like protease of Middle East respiratory syndrome coronavirus Antiviral Res 115 9-16 https://doi.org/10.1016/j.antiviral.2014.12.011

55. Chan JF, Chan KH, and Kao RY, et al (2013) Broad-spectrum antivirals for the emerging Middle East respiratory syndrome coronavirus J Infect 67(6) 606-616 https://doi.org/10.1016/j.jinf.2013.09.029 PMID: 24096239

56. Shen L, Niu J, and Wang C, et al (2019) High-throughput screening and identification of potent broad-spectrum inhibitors of coronaviruses J Virol 93(12) https://doi.org/10.1128/JVI.00023-19

57. Hart BJ, Dyall J, and Postnikova E, et al (2014) Interferon-beta and mycophenolic acid are potent inhibitors of Middle East respiratory syndrome coronavirus in cell-based assays J Gen Virol 95(Pt 3) 571-577 https://doi.org/10.1099/vir.0.061911-0 PMCID: 3929173

58. Mo Y and Fisher D (2016) A review of treatment modalities for Middle East Respiratory Syndrome J Antimicrob Chemother 71(12) 3340-3350 https://doi.org/10.1093/jac/dkw338 PMID: 27585965

59. Al Ghamdi M, Alghamdi KM, and Ghandoora Y, et al (2016) Treatment outcomes for patients with Middle Eastern Respiratory Syndrome Coronavirus (MERS CoV) infection at a coronavirus referral center in the Kingdom of Saudi Arabia BMC Infect Dis 16(1) 174 https://doi. org/10.1186/s12879-016-1492-4 PMID: 27097824 PMCID: 4839124

60. AlGhamdi M, Mushtaq F, and Awn N, et al (2015) MERS CoV infection in two renal transplant recipients: case report Am J Transplant 15(4) 1101-1104 https://doi.org/10.1111/ajt.13085 PMID: 25716741

61. Carbajo-Lozoya J, Müller MA, and Kallies S, et al (2012) Replication of human coronaviruses SARS-CoV, HCoV-NL63 and HCoV-229E is inhibited by the drug FK506 Virus Res 165(1) 112-117 https://doi.org/10.1016/j.virusres.2012.02.002 PMID: 22349148

62. Carbajo-Lozoya J, Ma-Lauer Y, and Malesevic M, et al (2014) Human coronavirus NL63 replication is cyclophilin A-dependent and inhibited by non-immunosuppressive cyclosporine A-derivatives including Alisporivir Virus Res 184 44-53 https://doi.org/10.1016/j. virusres.2014.02.010 PMID: 24566223 


\section{Supplementary tables of summarised literature}

Supplementary Table 1. Current studies investigating COVID-19 and cytotoxic chemotherapy.

\begin{tabular}{|c|c|c|c|c|c|}
\hline Study Ref & Title & Authors & $\begin{array}{c}\text { Country of } \\
\text { study }\end{array}$ & Year & Summary of results \\
\hline [1] & $\begin{array}{l}\text { The differential diagnosis of } \\
\text { pulmonary infiltrates in cancer pa- } \\
\text { tients during the outbreak of the } \\
2019 \text { novel coronavirus disease }\end{array}$ & Zhu et al & China & 2020 & $\begin{array}{l}\text { COVID-19 complicates the clinical scenario of pulmonary } \\
\text { infiltrates in cancer patients. Active treatment against the } \\
\text { infection and patient surveillance should be initiated if } \\
\text { infectious disease is considered. }\end{array}$ \\
\hline [2] & $\begin{array}{l}\text { Chemotherapy strategy for } \\
\text { colorectal cancer under the } \\
\text { outbreak of novel coronavirus } \\
\text { pneumonia }\end{array}$ & Li et al & China & 2020 & $\begin{array}{l}\text { Recommendations based on stage of cancer: } \\
\text { - Recurrent metastatic colorectal cancer: low-intensity } \\
\text { maintenance therapy } \\
\text { - Patients with tumour changes or higher malignancy } \\
\text { still need to receive combined chemotherapy. } \\
\text { - After radical surgery, given the relatively limited } \\
\text { benefits of adjuvant chemotherapy, the intensity and } \\
\text { duration of treatment can be reduced. } \\
\text { - In the face of patients with febrile tumour chemother- } \\
\text { apy, it is necessary to analyse the cause of the fever of } \\
\text { the patient. } \\
\text { - Stable disease and good general condition: elect to } \\
\text { delay the time of imaging evaluation. }\end{array}$ \\
\hline [3] & $\begin{array}{l}\text { Fatal encephalitis associated with } \\
\text { coronavirus OC43 in an immuno- } \\
\text { compromised child }\end{array}$ & Nilsson et al & Sweden & 2020 & $\begin{array}{l}\text { A one-year-old child with pre-B acute lymphoblastic } \\
\text { leukaemia (ALL) developed fatal encephalitis associated } \\
\text { with human coronavirus OC43 (HCoV-OC43). During } \\
\text { chemotherapy the child had a persistent HCoV-OC43 } \\
\text { respiratory infection and later developed progres- } \\
\text { sive encephalitis. Cerebrospinal fluid was negative for } \\
\text { pathogens including HCoV-OC43, but a brain biopsy was } \\
\text { HCoV-OC43-positive. }\end{array}$ \\
\hline [4] & $\begin{array}{l}\text { Recent developments in anti-se- } \\
\text { vere acute respiratory syndrome } \\
\text { coronavirus chemotherapy }\end{array}$ & $\begin{array}{l}\text { Barnard and } \\
\text { Kumaki }\end{array}$ & England & 2011 & $\begin{array}{l}\text { Anti-SARS-CoV therapies recently published from } 2007 \\
\text { to } 2010 \text { reviewed in this paper and the following com- } \\
\text { pounds have been shown to be active in vitro against the } \\
\text { virus: } \\
\text { TNF- } \alpha \text {-converting enzyme inhibitor (TAPI-2); IFN- } a \text { (B/D, } \\
\text { mDEF201 by adenovirus } 5 \text { vector, CR3014 humanised } \\
\text { monoclonal antibody, recombinant IFN-a2b and type I } \\
\text { IFN- } \beta \text { ); Interferon inducers (Ampligen and polyinosinic- } \\
\text { polycytidylic); } \\
\text { therapeutic antibodies ( } 2978 / 10 \text {, equine anti-SARS-CoV } \\
\text { F[ab'] and monoclonal antibody 201); attachment inhibi- } \\
\text { tors (Urtica Dioica lectin and griffithsin); host immune } \\
\text { system. }\end{array}$ \\
\hline
\end{tabular}


Supplementary Table 1. Current studies investigating COVID-19 and cytotoxic chemotherapy. (continued)

\begin{tabular}{|c|c|c|c|c|c|}
\hline [5] & $\begin{array}{l}\text { A 3-Year Retrospective Study of } \\
\text { the Epidemiology of Acute Respi- } \\
\text { ratory Viral Infections in Pediatric } \\
\text { Patients With Cancer Undergoing } \\
\text { Chemotherapy }\end{array}$ & $\begin{array}{l}\text { Aydin Köker } \\
\text { et al }\end{array}$ & Turkey & 2019 & $\begin{array}{l}\text { - Nasopharyngeal aspirates were analysed in patients } \\
\text { younger than } 21 \text { years with acute respiratory infec- } \\
\text { tions. } \\
\text { - Coinfection with } 2 \text { viruses was present in } 20.5 \% \\
(45 / 219) \text { of the episodes. } \\
\text { - Most frequent coinfections of respiratory viruses: } 6 \\
\text { cases of HRV+hBoV, } 5 \text { of HRV, +AdRV, } 4 \text { of PI3+CoV } \\
43,3 \text { of HRV+CoV } 43,3 \text { of HRV, +IF A/H1N1, } 3 \text { of } \\
\text { HRV+RSV A/B, and } 2 \text { of HRV+EV } \\
\text { - Detected more often in the months of January (16\%) } \\
\text { and October (15\%) than in the other months } \\
\text { - Conclusion: no increase in mortality of cancer patients } \\
\text { but cause for significant delays to chemotherapy, } \\
\text { which might have an indirect impact on patient sur- } \\
\text { vival rates. }\end{array}$ \\
\hline [6] & $\begin{array}{l}\text { Frequent Respiratory Viral Infec- } \\
\text { tions in Children with Febrile } \\
\text { Neutropenia - A Prospective } \\
\text { Follow-Up Study }\end{array}$ & $\begin{array}{l}\text { Söderman } \\
\text { et al }\end{array}$ & Sweden & 2016 & $\begin{array}{l}\text { - Nasopharyngeal aspirates were collected during } 87 \\
\text { episodes of febrile neutropenia in children age 0-18 } \\
\text { years } \\
\text { - No symptoms were apparent in four episodes involv- } \\
\text { ing RV and one episode involving HCoV } \\
\text { - Persistent HCoV with a median follow-up time of } 31 \\
\text { days } \\
\text { - High viral loads were correlated to more symptoms } \\
\text { - Respiratory viruses play an etiologic role in febrile } \\
\text { neutropenia in children receiving treatment for a } \\
\text { malignancy. }\end{array}$ \\
\hline [7] & $\begin{array}{l}\text { An Overview of Severe Acute Re- } \\
\text { spiratory Syndrome-Coronavirus } \\
\text { (SARS-CoV) } 3 \text { CL Protease Inhibi- } \\
\text { tors: Peptidomimetics and Small } \\
\text { Molecule Chemotherapy }\end{array}$ & Pillaiyar et al & USA & 2016 & $\begin{array}{l}\text { The paper focuses on on the status of various } \\
\text { efficacious anti-SARS-CoV } 3 \text { CLpro chemotherapies } \\
\text { discovered during the last } 12 \text { years (2003-2015) from } \\
\text { all sources, including laboratory synthetic methods, } \\
\text { natural products, and virtual screening. } \\
\text { - Conclusion: No coronavirus protease inhibitor has } \\
\text { yet successfully completed a preclinical development } \\
\text { program }\end{array}$ \\
\hline [8] & $\begin{array}{l}\text { Respiratory Viral Infections in } \\
\text { Patients With Cancer or Undergo- } \\
\text { ing Hematopoietic Cell Transplant. } \\
\text { [Review] }\end{array}$ & Hijano et al & Switzerland & 2018 & $\begin{array}{l}\text { - Clinical manifestations vary significantly depending on } \\
\text { the type of virus and the type and degree of immuno- } \\
\text { suppression. } \\
\text { - Risk factors associated with prolonged viral shedding } \\
\text { can include viral load, use of steroids, and myeloabla- } \\
\text { tive conditioning. } \\
\text { - Mortality associated with coronavirus in HCT } \\
\text { recipients was inconclusive. While some studies [9] } \\
\text { reported no associations, other studies [10] reported } \\
\text { similar mortality rates in HCT recipients to those } \\
\text { observed with other viruses such as RSV, influenza } \\
\text { virus, and PIV. }\end{array}$ \\
\hline
\end{tabular}


Supplementary Table 1. Current studies investigating COVID-19 and cytotoxic chemotherapy. (continued)

\begin{tabular}{|c|c|c|c|c|c|}
\hline [11] & $\begin{array}{l}\text { Progress in Anti-SARS Corona- } \\
\text { virus Chemistry, Biology and } \\
\text { Chemotherapy }\end{array}$ & Ghosh et al & USA & 2007 & $\begin{array}{l}\text { - SARS-CoV proteases are attractive targets for the } \\
\text { development of antiviral drugs to reduce viral replica- } \\
\text { tion and pathogenicity. } \\
\text { - Glycyrrhizin showed inhibitory activity for SARS-CoV } \\
\text { replication but it has high cytotoxicity. } \\
\text { - HIV protease inhibitor nelfinavir, antihelminthic drug } \\
\text { niclosamide and antimalarial agent chloroquine have } \\
\text { also showed strong inhibitory activity against SARS- } \\
\text { CoV replication. } \\
\text { - A human IgG1 form of 80R was found to bind the } \\
\text { S1 domain of the SARS-CoV S protein (with a higher } \\
\text { affinity comparable to that of ACE2 suggesting that } \\
\text { the } 80 R \text { human monoclonal antibody is a useful viral } \\
\text { entry inhibitor for SARS treatment. }\end{array}$ \\
\hline [12] & $\begin{array}{l}\text { Alternative screening approaches } \\
\text { for discovery of Middle East } \\
\text { respiratory syndrome coronavirus } \\
\text { inhibitors }\end{array}$ & LaFemina, RL. & USA & 2014 & $\begin{array}{l}\text { - Lopinavir is an HIV protease inhibitor. } \\
\text { - Lopinavir has been suggested as a low-micromolar } \\
\text { inhibitor of MERS-CoV. } \\
\text { - However, proteases of HIV and coronaviruses fall into } \\
\text { different mechanistic classes of proteases. }\end{array}$ \\
\hline [13] & $\begin{array}{l}\text { Acute respiratory viral infections } \\
\text { in paediatric cancer patients } \\
\text { undergoing chemotherapy }\end{array}$ & Benites et al & Brazil & 2014 & $\begin{array}{l}\text { - Paediatric patients with cancer and acute respiratory } \\
\text { infection [14] and/or fever. } \\
\text { - Coronavirus was identified in } 6.8 \% \text { in the } 50 \text { samples } \\
\text { of respiratory cases. } \\
\text { - Human rhinovirus (HRV) was the most common viral } \\
\text { pathogen, followed by coronavirus, respiratory syncy- } \\
\text { tial virus (RSV), and metapneumovirus, demonstrating } \\
\text { the importance of these pathogens in the studied } \\
\text { population. } \\
\text { - The prevalence of respiratory viruses was relevant in } \\
\text { the infectious episode, with no increase in morbid- } \\
\text { ity and mortality. Viral co-detection was frequent in } \\
\text { patients with cancer and ARIs. } \\
\text { - The link of whether severe acute infection was } \\
\text { directly related to the type of cancer or viral pathogen } \\
\text { was not identified in the study. }\end{array}$ \\
\hline [15] & $\begin{array}{l}\text { Thiopurine analogue inhibi- } \\
\text { tors of severe acute respiratory } \\
\text { syndrome-coronavirus papain-like } \\
\text { protease, a deubiquitinating and } \\
\text { delSGylating enzyme }\end{array}$ & Chen et al & Taiwan & 2009 & $\begin{array}{l}\text { 6-mercaptopurine (6MP) and 6-thioguanine (6TG) } \\
\text { have been used in cancer chemotherapy for treatment } \\
\text { of acute lymphoblastic or myeloblastic leukaemia } \\
\text { and were found to be specific inhibitors for the SARS } \\
\text { coronavirus. }\end{array}$ \\
\hline [14] & $\begin{array}{l}\text { Carbohydrate-binding agents: a } \\
\text { potential future cornerstone for } \\
\text { the chemotherapy of enveloped } \\
\text { viruses? }\end{array}$ & Balzarini, J. & Belgium & 2007 & $\begin{array}{l}\text { - Carbohydrate-binding agents (CBA) may be able to } \\
\text { block enveloped viruses other than HIV in their entry } \\
\text { process and coronaviruses and influenza viruses are } \\
\text { other examples of enveloped viruses that may be } \\
\text { highly susceptible to the antiviral action of CBAs. } \\
\text { - In HIV, glycan deletions in gp120 delays the spread of } \\
\text { virus. } \\
\text { - CBA administration may bring the viral infection under } \\
\text { control before glycan deletions occur and the immune } \\
\text { system can get involved in the further clearance of } \\
\text { the virus. }\end{array}$ \\
\hline
\end{tabular}


Supplementary Table 1. Current studies investigating COVID-19 and cytotoxic chemotherapy. (continued)

\begin{tabular}{|c|c|c|c|c|c|}
\hline [16] & $\begin{array}{l}\text { Molecular biology investigation of } \\
\text { respiratory viruses as a factor of } \\
\text { infectious complications in hemo- } \\
\text { blastosis and myelodepression }\end{array}$ & $\begin{array}{l}\text { Chebotkevich } \\
\text { et al }\end{array}$ & Russia & 2006 & $\begin{array}{l}\text { Only abstract available, article in Russian and not acces- } \\
\text { sible. } \\
\text { - Communicable respiratory viruses were investigated } \\
\text { in } 51 \text { patients as a causative factor of infectious com- } \\
\text { plication in hemoblastosis and myelodepression } \\
\text { - Coronaviruses detected in } 13.7 \%\end{array}$ \\
\hline [17] & $\begin{array}{l}\text { Synthesis of novel test com- } \\
\text { pounds for antiviral chemother- } \\
\text { apy of severe acute respiratory } \\
\text { syndrome [18]. [Review] }\end{array}$ & Kesel AJ & $\begin{array}{l}\text { United Arab } \\
\text { Emirates }\end{array}$ & 2005 & $\begin{array}{l}\text { - } 25 \text { test materials including interferon-inducer } \\
\text { - Bananin (BN) was an effective inhibitor of SARS-CoV } \\
\text { in cell culture. }\end{array}$ \\
\hline [19] & $\begin{array}{l}\text { Induction of Th1 type response by } \\
\text { DNA vaccinations with } \mathrm{N}, \mathrm{M} \text {, and } \\
\text { E genes against SARS-CoV in mice }\end{array}$ & Huali et al & China & 2005 & $\begin{array}{l}\text { - The } \mathrm{M} \text { and } \mathrm{E} \text { are play a role in coronaviral particle } \\
\text { assembling. Targeting these agents may lead to } \\
\text { immune responses by inducing the production of } \\
\text { protective IFN-a. } \\
\text { - } \mathrm{N}, \mathrm{M} \text {, and E genes may be used as the targets to } \\
\text { prevent SARS-CoV infection. }\end{array}$ \\
\hline [20] & $\begin{array}{l}\text { A system of protein target } \\
\text { sequences for anti-RNA-viral } \\
\text { chemotherapy by a vitamin B6- } \\
\text { derived zinc-chelating trioxa- } \\
\text { adamantane-triol. }\end{array}$ & Keseal AJ. & Germany & 2003 & $\begin{array}{l}\text { - Bananin acts as zinc ( } \mathrm{Zn} 2+\text { ) chelator } \\
\text { - Targets and inhibits zinc finger of HIV-1 RNA-binding } \\
\text { nucleocapsid protein p7 (NCp7). } \\
\text { - Bananin is converted to bananin 5'-monophosphate } \\
\text { (BNP) which together with B6RA (vitamin A-vitamin } \\
\text { B6 conjugate) and could inhibit infectious virion } \\
\text { encapsidation. } \\
\text { - Targets of BNP and B6RA have shown to be present } \\
\text { also in SARS-associated coronavirus making them } \\
\text { possible therapeutic candidates. }\end{array}$ \\
\hline [21] & $\begin{array}{l}\text { Coronavirus Pneumonia } \\
\text { Following Autologous Bone } \\
\text { Marrow Transplantation for } \\
\text { Breast Cancer }\end{array}$ & $\begin{array}{l}\text { Folz and } \\
\text { Elkordy }\end{array}$ & USA & 1999 & $\begin{array}{l}\text { - Case report: coronavirus in woman with stage III } \\
\text { breast cancer following treatment with hig-dose } \\
\text { chemotherapy and autologous bone marrow and stem } \\
\text { cell transplant. }\end{array}$ \\
\hline
\end{tabular}

Supplementary Table 2. Current studies investigating COVID-19/ other coronavirus strains and low-dose steroids.

\begin{tabular}{|c|l|l|l|l|l|}
\hline Study Ref & \multicolumn{1}{|c|}{ Title } & \multicolumn{1}{|c|}{ Authors } & $\begin{array}{c}\text { Country of } \\
\text { study }\end{array}$ & Year & \multicolumn{1}{c|}{ Summary of results } \\
\hline$[22]$ & $\begin{array}{l}\text { Understanding SARS-CoV-2-Me- } \\
\text { diated Inflammatory Responses: } \\
\text { From Mechanisms to Potential } \\
\text { Therapeutic Tools }\end{array}$ & $\begin{array}{l}\text { Fu, Cheng } \\
\text { and Wu }\end{array}$ & China & 2020 & $\begin{array}{l}\text { This review suggests that: } \\
\text { SARS-CoV S protein can downregulate ACE2 } \\
\text { - Loss of pulmonary ACE2 function has been suggested } \\
\text { to be associated with acute lung injury; the reduction } \\
\text { in ACE2 function can cause dysfunction of the renin- } \\
\text { angiotensin system [23] and enhance inflammation } \\
\text { and vascular permeability. }\end{array}$ \\
& & & $\begin{array}{l}\text { ACE2-associated lung injury has been suggested in } \\
\text { SARS- CoV infection } \\
\text { From reading this article the following article was then } \\
\text { discovered... }\end{array}$ \\
\hline
\end{tabular}


Supplementary Table 2. Current studies investigating COVID-19/ other coronavirus strains and low-dose steroids. (continued)

\begin{tabular}{|c|c|c|c|c|c|}
\hline [24] & $\begin{array}{l}\text { Are patients with hypertension } \\
\text { and diabetes mellitus at increased } \\
\text { risk for COVID-19 infection? }\end{array}$ & $\begin{array}{l}\text { Fang, Kara- } \\
\text { kiulakis and } \\
\text { Roth }\end{array}$ & Greece & 2020 & $\begin{array}{l}\text { The expression of ACE2 is substantially increased in } \\
\text { patients with type } 1 \text { or type } 2 \text { diabetes, who are treated } \\
\text { with ACE inhibitors and angiotensin II type-I receptor } \\
\text { blockers (ARBs). Hypertension is also treated with ACE } \\
\text { inhibitors and ARBs, which results in an upregulation of } \\
\text { ACE2 } \\
\text { ACE2 can be increased by thiazolidinediones and } \\
\text { ibuprofen. These data suggest that ACE2 expression is } \\
\text { increased in diabetes and treatment with ACE inhibitors } \\
\text { and ARBs increases ACE2 expression. Consequently, the } \\
\text { increased expression of ACE2 would facilitate infection } \\
\text { with COVID-19. } \\
\text { The authors therefore hypothesise that diabetes and } \\
\text { hypertension treatment with ACE2-stimulating drugs } \\
\text { increases the risk of developing severe and fatal CO- } \\
\text { VID-19. }\end{array}$ \\
\hline [25] & $\begin{array}{l}\text { Drug treatment options for the } \\
\text { 2019-new coronavirus (2019- } \\
\text { nCoV) }\end{array}$ & Lu & China & 2020 & $\begin{array}{l}\text { No evidence given for or against using ibuprofen only } \\
\text { that 'anti-inflammatory drugs (such as hormones and } \\
\text { other molecules)' are potential therapeutic options for } \\
\text { 2019-nCoV. }\end{array}$ \\
\hline [26] & $\begin{array}{l}\text { Severe acute respiratory syn- } \\
\text { drome: clinical and laboratory } \\
\text { manifestations. }\end{array}$ & $\begin{array}{l}\text { Lam, Chan, } \\
\text { Wong }\end{array}$ & China & 2004 & $\begin{array}{l}\text { Corticosteroid treatment reduced interleukin } 8 \text { (IL-8), } \\
\text { monocyte chemoattractant protein-1 (MCP-1) and IFN- } \\
\gamma \text {-inducible protein-10 (IP-10) concentrations from } 5 \text { - } 8 \\
\text { days after treatment in SARS patients. These were all } \\
\text { inflammatory markers which were remarkably increased } \\
\text { in SARS patients. NB. This study is not specifically look- } \\
\text { ing at SARS-CoV2 only at SARS-CoV. }\end{array}$ \\
\hline [27] & $\begin{array}{l}\text { Decoding the enigma of antiviral } \\
\text { crisis: Does one target molecule } \\
\text { regulate all? }\end{array}$ & $\begin{array}{l}\text { Mahmud-Al- } \\
\text { Rafat et al }\end{array}$ & $\begin{array}{l}\text { Bangladesh, } \\
\text { Germany, } \\
\text { Canada, UK } \\
\text { and Australia }\end{array}$ & 2019 & $\begin{array}{l}\text { This review article aimed to look at multiple diseases } \\
\text { caused by various viruses including Dengue, Ebola and } \\
\text { SARS-CoV. They stated that ribavirin (an antiviral) is the } \\
\text { most frequently used drug to combat SARS-CoV, and } \\
\text { is administered together with corticosteroids. } \\
\text { Although immunosuppressive corticosteroid drugs are } \\
\text { commonly used in an attempt to reduce fatality rates, the } \\
\text { results of clinical trials are not sufficiently satisfactory to } \\
\text { approve as an effective class of therapeutic } \\
\text { Glucocorticoid-mediated stimulation of the hypotha- } \\
\text { lamic-pituitaryadrenal axis can also drive lymphocyto- } \\
\text { penia, or it may promote exaggerated pro-inflammatory } \\
\text { responses that eventually cause a worsening of the } \\
\text { pathogenic condition. (Please note this is not specific } \\
\text { for SARS-CoV-19 and is referring to the } 3 \text { viral diseases } \\
\text { mentioned). }\end{array}$ \\
\hline
\end{tabular}


Supplementary Table 2. Current studies investigating COVID-19/ other coronavirus strains and low-dose steroids. (continued)

\begin{tabular}{|c|c|c|c|c|c|}
\hline [28] & $\begin{array}{l}\text { The management of coronavirus } \\
\text { infections with particular refer- } \\
\text { ence to SARS. }\end{array}$ & $\begin{array}{l}\text { Wong SS, } \\
\text { Yuen KY }\end{array}$ & & 2008 & $\begin{array}{l}\text { HCoV-OC43 and HCoV-229E initial principal pathogens } \\
\text { discovered in } 1960 \text { 's; acute respiratory diseases of less } \\
\text { severity and mortality than SARS-CoV which promoted } \\
\text { rapid search for effective antiviral treatments. } \\
\text { Immunomodulatory agents (primarily corticosteroids) } \\
\text { widely used during SARS to avoid excessive tissue dam- } \\
\text { age by cytokine dysregulation but benefit of use not } \\
\text { conclusively demonstrated. } \\
\text { Multiple studies demonstrated increased plasma viral load } \\
\text { with use of corticosteroids (RCT measured plasma viral } \\
\text { load at regular intervals in non-intubated cases found } \\
\text { higher concentrations of SARS-CoV RNA in week } 2 / 3 \text { of } \\
\text { illness compared to patients who received placebo). } \\
9.9 \% \text { of patients in Hong Kong cohort study also suf- } \\
\text { fered opportunitistic infections such as aspergillosis and } \\
\text { late sequelae (including avascular osteonecrosis) with } \\
\text { corticosteroid use. }\end{array}$ \\
\hline [29] & $\begin{array}{l}\text { Cytokine responses in porcine } \\
\text { respiratory coronavirus-infected } \\
\text { pigs treated with corticosteroids } \\
\text { as a model for severe acute respi- } \\
\text { ratory syndrome. }\end{array}$ & $\begin{array}{l}\text { Zhang X, } \\
\text { Alekseev K, } \\
\text { Jung K, Vla- } \\
\text { sova A, Hadya } \\
\text { N, Saif LJ }\end{array}$ & USA & 2008 & $\begin{array}{l}\text { Laboratory study which treated porcine respiratory coro- } \\
\text { navirus infected pigs with corticosteroid dexamethasone } \\
\text { as a model for SARS. } \\
\text { Goal to define whether corticosteroid treatment altered } \\
\text { immunity and lung inflammatory response at cytokine } \\
\text { level and how changes correlated with pig lung lesions. } \\
\text { Confirmed infection model applicable and resembled SARS. } \\
\text { Treatment with dexamethasone suppressed early local } \\
\text { IL-6 levels but increased later on in disease. Suggests } \\
\text { may decrease inflammation at early infection stage but } \\
\text { not later. } \\
\text { Results also suggest that dexamethasone induced reduc- } \\
\text { tion of IL-6 might play a role in delayed onset of lung } \\
\text { lesions but increases of IL-6 at later infection stage may } \\
\text { contribute to severity of lung lesions (mimicking delayed } \\
\text { onset of disease severity as seen in SARS patients } \\
\text { treated with corticosteroids). } \\
\text { Overall findings suggest that } 1 \text { or } 2 \text { doses of dexametha- } \\
\text { sone in acute phase of infection may effectively alleviate } \\
\text { early pro-inflammatory response, but prolonged DEX ad- } \\
\text { ministration may play role in enhancing viral replication. }\end{array}$ \\
\hline [30] & $\begin{array}{l}\text { Indomethacin has a potent } \\
\text { antiviral activity against SARS } \\
\text { coronavirus. }\end{array}$ & $\begin{array}{l}\text { Amici C, } \\
\text { Di Caro A, } \\
\text { Ciucci A, } \\
\text { Chiappa L, } \\
\text { Castilletti C, } \\
\text { Martella V, } \\
\text { Decaro N, } \\
\text { Buonavoglia } \\
\text { C, Capobi- } \\
\text { anchi MR, } \\
\text { Santoro MG }\end{array}$ & Italy & 2006 & $\begin{array}{l}\text { Utilised observation that cyclopentenone cyclooxygen- } \\
\text { ase (COX) metabolites are active against several RNA } \\
\text { viruses to investigate effect of COX inhibitor indometha- } \\
\text { cin on coronavirus replication. } \\
\text { Indomethacin is common NSAID. } \\
\text { Report describes how indomethacin was unexpectedly } \\
\text { found to possess potent antiviral activity against canine } \\
\text { coronavirus (dramatically inhibit virus replication and } \\
\text { protect the host cell from virus-induced damage). } \\
\text { Activity also observed in vivo and against human SARS-CoV. } \\
\text { Oral administration of concentration } 1 \mathrm{mg} / \mathrm{kg} \text { found to be } \\
\text { effective. }\end{array}$ \\
\hline
\end{tabular}


Supplementary Table 2. Current studies investigating COVID-19/ other coronavirus strains and low-dose steroids. (continued)

\begin{tabular}{|c|c|c|c|c|c|}
\hline [31] & $\begin{array}{l}\text { A study of pulmonary inflammato- } \\
\text { ry reaction induced by } \mathrm{N} \text {-protein } \\
\text { of SARS-CoV in rat models and } \\
\text { effects of glucocorticoids on it }\end{array}$ & $\begin{array}{l}\text { Hao D, He LX, } \\
\text { Qu JM, Pan J, } \\
\text { Hu BJ, Zhang } \\
\text { J, Li ZZ }\end{array}$ & $\begin{array}{l}\text { China (full } \\
\text { article only } \\
\text { available in } \\
\text { Chinese but } \\
\text { informative } \\
\text { abstract) }\end{array}$ & 2005 & $\begin{array}{l}\text { Studied pulmonary inflammatory reaction induced by } \\
\mathrm{N} \text {-protein of SARS-CoV in rat models and effects of } \\
\text { glucocorticoids on inflammatory reaction. } \\
\text { Mice treated with dexamethasone. } \\
\mathrm{N} \text {-protein of SARS-CoV shown to have pathogenicity in- } \\
\text { ducing pulmonary inflammatory reaction and acute lung } \\
\text { injury which were related to the increase and imbalance } \\
\text { of pro-inflammatory and anti-inflammatory cytokines. } \\
\text { Glucocorticoids (dexamethasone) demonstrated effec- } \\
\text { tively alleviate pulmonary inflammatory reaction. }\end{array}$ \\
\hline [32] & $\begin{array}{l}\text { Overview of antiviral and anti- } \\
\text { inflammatory treatment for severe } \\
\text { acute respiratory syndrome. }\end{array}$ & $\begin{array}{l}\text { Chihrin S, } \\
\text { Loutfy MR }\end{array}$ & Canada & 2014 & $\begin{array}{l}\text { Anti-inflammatory agents heavily utilised during SARS } \\
\text { outbreak as it was believed that the development and } \\
\text { worsening of the pulmonary disease had inflammatory } \\
\text { aetiology and pathogenesis. } \\
\text { Immunopathological analysis of } 20 \text { SARS patients } \\
\text { demonstrated increased Th1 cytokine interferon y and } \\
\text { inflammatory cytokines IL-1, IL-6 and IL-12 for > } 2 \text { weeks } \\
\text { following onset of symptoms. } \\
\text { Also observed decrease in viral activity and IgG sero- } \\
\text { conversion during 2nd week of illness despite general } \\
\text { progression of respiratory disease- suggesting respiratory } \\
\text { damage is secondary to immune-mediated inflammatory } \\
\text { response. } \\
\text { Corticosteroids used during SARS outbreak for their abil- } \\
\text { ity to module variety of involved cytokines. } \\
\text { Numerous papers published outcomes of patients } \\
\text { administered corticosteroids (mostly IV hydrocortisone } \\
\text { or methylprednisolone) in either early low-dose or } \\
\text { pulsed-dose strategies. Most concluded corticosteroids } \\
\text { appeared to be effective in reducing immunopathologi- } \\
\text { cal damage (resulting in improved and rapid resolution of } \\
\text { symptoms). } \\
\text { Opposition to corticosteroid use centred around use } \\
\text { of corticosteroid use in treatment of acute respiratory } \\
\text { distress syndrome- concern that corticosteroid treat- } \\
\text { ment may weaken immune response and promote viral } \\
\text { rebound. Reports also add evidence to theory. } \\
\text { Further opposition includes association with adverse } \\
\text { events such as hyperglycaemia, hypokalaemia, hyper- } \\
\text { tension, gastrointestinal haemorrhage and avascular } \\
\text { necrosis (AVN). }\end{array}$ \\
\hline [33] & $\begin{array}{l}\text { High-dose hydrocortisone } \\
\text { reduces expression of the pro- } \\
\text { inflammatory chemokines CXCL8 } \\
\text { and CXCL10 in SARS coronavirus- } \\
\text { infected intestinal cells. }\end{array}$ & $\begin{array}{l}\text { Cinatl J Jr, } \\
\text { Michaelis M, } \\
\text { Morgenstern } \\
\text { B, Doerr HW }\end{array}$ & $\begin{array}{l}\text { Germany } \\
\text { (needs to be } \\
\text { purchased) }\end{array}$ & 2005 & $\begin{array}{l}\text { Investigated influence of SARS-CoV infection on CXCL8 } \\
\text { and CXCL10 in human intestinal epithelial cells. } \\
\text { High concentrations of hydrocortisone prevented DNA } \\
\text { binding activity of AP-1 and NF-kappabeta and inhibited } \\
\text { upregulation of CXCL8 and CXCL10 but did not reduce } \\
\text { chemokine expression to basal. } \\
\text { Results suggest corticosteroid may be of limited benefit } \\
\text { in suppression of chemokine production by SARS-CoV } \\
\text { infected cells. }\end{array}$ \\
\hline
\end{tabular}


Supplementary Table 2. Current studies investigating COVID-19/ other coronavirus strains and low-dose steroids. (continued)

\begin{tabular}{|c|c|c|c|c|c|}
\hline [34] & $\begin{array}{l}\text { Plasma inflammatory cytokines } \\
\text { and chemokines in severe acute } \\
\text { respiratory syndrome. }\end{array}$ & $\begin{array}{l}\text { Wong CK, } \\
\text { Lam CW, Wu } \\
\text { AK, Ip WK, } \\
\text { Lee NL, Chan } \\
\text { IH, Lit LC, Hui } \\
\text { DS, Chan MH, } \\
\text { Chung SS, } \\
\text { Sung JJ }\end{array}$ & Hong Kong & 2004 & $\begin{array}{l}\text { Overproduction of TNF-alpha, IL-1, IL-6 and IL-10 hall- } \\
\text { mark of viral infection. } \\
\text { Investigated inflammatory profiles of patients infected } \\
\text { with SARS in Hong Kong hospital. } \\
\text { Use of corticosteroids significantly reduced IL-8, MCP-1 } \\
\text { and IP-10 concentrations from 5-8 days after treatment. }\end{array}$ \\
\hline [35] & $\begin{array}{l}\text { Description and clinical treatment } \\
\text { of an early outbreak of severe } \\
\text { acute respiratory syndrome [18] } \\
\text { in Guangzhou, PR China. }\end{array}$ & $\begin{array}{l}\text { Zhao Z, } \\
\text { Zhang F, Xu } \\
\text { M, Huang } \\
\text { K, Zhong W, } \\
\text { Cai W, Yin } \\
\text { Z, Huang S, } \\
\text { Deng Z, Wei } \\
\text { M, Xiong J, } \\
\text { Hawkey PM }\end{array}$ & China & 2003 & $\begin{array}{l}\text { Patients treated in different methods. } 2 \text { groups of } 4 \\
\text { received steroids (in form of methyl prednisolone). } \\
\text { Early use of high-dose steroids appeared to help } \\
\text { recovery from SARS. } \\
\text { Early use of high-dose steroids in combination with a } \\
\text { quinolone plus azithromycin gave the best outcome with } \\
\text { improvement of clinical signs and symptoms, decreased } \\
\text { incidence of ARDs and mechanical ventilation as well as } \\
\text { mortality. } \\
\text { Hypothesised that steroids may help by reducing the } \\
\text { damaging effect of the local inflammatory response. }\end{array}$ \\
\hline
\end{tabular}

Supplementary Table 3. Current studies investigating COVID-19/other coronavirus strains and TNF blockers. (continued)

\begin{tabular}{|c|c|c|c|c|c|}
\hline Study Ref & Title & Authors & $\begin{array}{c}\text { Country of } \\
\text { study }\end{array}$ & Year & Summary of results \\
\hline [36] & $\begin{array}{l}\text { TNF-alpha inhibition for potential } \\
\text { therapeutic modulation of SARS } \\
\text { coronavirus infection. }\end{array}$ & Tobinick E. & US & 2004 & $\begin{array}{l}\text { - Clinical and experimental evidence implicate TNF as } \\
\text { a possible mediator of the severe immune-based pul- } \\
\text { monary injury which can follow infection with H5N1 } \\
\text { influenza and SARS coronavirus. } \\
\text { - In humans, anti-TNF therapy utilising etanercept has } \\
\text { been reported to be beneficial for treatment of the } \\
\text { non-infectious idiopathic pneumonia syndrome which } \\
\text { can follow stem-cell transplantation, a pulmonary } \\
\text { syndrome that resembles SARS pneumonia in some } \\
\text { respect. } \\
\text { - If the SARS coronavirus does indeed lead to massive } \\
\text { release of TNF-af rom alveolar macrophages, then } \\
\text { early inhibition of TNF-a might be able to prevent } \\
\text { TNF-amediated immune activation and therefore } \\
\text { reduce pulmonary injury in these patients. } \\
\text { Compared with the use of corticosteroids, the use of } \\
\text { biologic TNF inhibitors, including etanercept, has the } \\
\text { potential to be a more specific and more effective } \\
\text { method of ameliorating the severe alveolar damage } \\
\text { which can occur following infection with these agents. }\end{array}$ \\
\hline
\end{tabular}


Supplementary Table 3. Current studies investigating COVID-19/other coronavirus strains and TNF blockers. (continued)

\begin{tabular}{|l|l|l|l|l|l|}
\hline [37] & $\begin{array}{l}\text { Anti-TNF alpha therapy does not } \\
\text { ameliorate disease in a model of } \\
\text { acute virus-endotoxin mediated } \\
\text { respiratory disease in pigs. }\end{array}$ & $\begin{array}{l}\text { Atanasova K; } \\
\text { Van Gucht S; } \\
\text { Van Reeth K. }\end{array}$ & Netherlands & 2010 & $\begin{array}{l}22 \text { piglets were assessed to to elucidate the role of } \\
\text { TNF-a in the development of virus-endotoxin-induced } \\
\text { respiratory disease. } \\
\text { The study demonstrates that after intratracheal admin- } \\
\text { istration etanercept is able to successfully block TNF-a } \\
\text { activity in vivo in the lungs of PRCV-LPS inoculated pigs } \\
\text { during the first 4-8 HPI. } \\
\text { TNF-a reduction, however, was not associated with } \\
\text { decrease in disease severity, bronchoalveolar neutrophil } \\
\text { infiltration, or altered virus replication and induction of } \\
\text { IL-1, IL-6, IL-12/IL-23 or IFN-a in the lungs. } \\
\text { There was no obvious difference in macroscopic lung } \\
\text { lesions and histopathological findings in the lungs. } \\
\text { This data confirms the generally accepted belief that } \\
\text { TNF-a, though very important, is not the sole culprit in } \\
\text { development of respiratory disease and pathology, and } \\
\text { possibly other, yet unidentified, components and mecha- } \\
\text { nisms of the immune system are involved. }\end{array}$ \\
\hline
\end{tabular}

Supplementary Table 4. Current studies investigating COVID-19/ other coronavirus strains and IL-6. (continued)

\begin{tabular}{|c|c|c|c|c|c|}
\hline Study Ref & Title & Authors & $\begin{array}{c}\text { Country of } \\
\text { study }\end{array}$ & Year & Summary of results \\
\hline [38] & $\begin{array}{l}\text { Diagnostic Utility of Clinical } \\
\text { Laboratory Data Determinations } \\
\text { for Patients with the Severe } \\
\text { COVID-19. }\end{array}$ & $\begin{array}{l}\text { Gao Y; Li T; } \\
\text { Han M; Li X; } \\
\text { Wu D; Xu Y; } \\
\text { Zhu Y; Liu } \\
\text { Y; Wang X; } \\
\text { Wang L. }\end{array}$ & China & 2020 & $\begin{array}{l}\text { - They investigated forty-three adult patients with } \\
\text { COVID-19. The patients were classified into mild } \\
\text { group ( } 28 \text { patients) and severe group (15 patients). } \\
\text { - Comparison of the haematological parameters } \\
\text { between the mild and severe groups showed signifi- } \\
\text { cant differences in IL-6, D-Dimer, GLU, TT, FIB and } \\
\text { CRP ( } p<0.05 \text { ). } \\
\text { - Infection-related biomarkers appeared to differ } \\
\text { between the two groups (IL-6).However, the propor- } \\
\text { tion of IL-6 above normal was [36.10( } 23.00,59.20) \text { pg/ } \\
\text { mL]in the severe group, which was significantly higher } \\
\text { than that in the mild group [10.60(5.13,24.18) pg/mL]. } \\
\text { - The AUC of IL-6 which was used to predict the sever- } \\
\text { ity of COVID-19 was } 0.795 \text { (P<0.0001), which could } \\
\text { better predict whetherrCOVID-19 was complicated } \\
\text { by severe pneumonia. The optimum critical point of } \\
\text { IL-6 in the group was } 24.3 \text { pg/ml, which was the upper } \\
\text { limit of no severe pneumonia. } \\
\text { - IL-6 and D-Dimer were closely related to the occur- } \\
\text { rence of severe COVID-19 in the adult patients, and } \\
\text { their combined detection had the highest specificity } \\
\text { and sensitivity for early prediction of the severity of } \\
\text { COVID-19 patients. }\end{array}$ \\
\hline
\end{tabular}


Supplementary Table 4. Current studies investigating COVID-19/ other coronavirus strains and IL-6. (continued)

\begin{tabular}{|c|c|c|c|c|c|}
\hline [39] & $\begin{array}{l}\text { Induction of pro-inflammatory } \\
\text { cytokines (IL-1 and IL-6) and lung } \\
\text { inflammation by COVID-19: anti- } \\
\text { inflammatory strategies. }\end{array}$ & $\begin{array}{l}\text { Conti, P; } \\
\text { Ronconi, G; } \\
\text { Caraffa, A; } \\
\text { Gallenga, } \\
\text { C; Ross, R; } \\
\text { Frydas, I; } \\
\text { Kritas, S. }\end{array}$ & Italy & 2020 & $\begin{array}{l}\text { - When COVID-19 infect the upper and lower respira- } \\
\text { tory tract it can cause mild or highly acute respiratory } \\
\text { syndrome with consequent release of pro-inflamma- } \\
\text { tory cytokines, including interleukin (IL)-1b and IL-6. } \\
\text { - The binding of COVID-19 to the Toll Like Receptor } \\
\text { (TLR) causes the release of pro-IL-1b which is cleaved } \\
\text { by caspase-1, followed by inflammasome activation } \\
\text { and production of active mature IL-1b which is a } \\
\text { mediator of lung inflammation, fever and fibrosis. } \\
\text { - Proinflammatory cytokines levels are correlated with } \\
\text { COVID-19 replication and disease. } \\
\text { - Suppression of pro-inflammatory IL-1 family mem- } \\
\text { bers and IL-6 have been shown to have a therapeutic } \\
\text { effect in many inflammatory diseases, including viral } \\
\text { infections. }\end{array}$ \\
\hline [40] & $\begin{array}{l}\text { Inhibitory effects of glycopyrro- } \\
\text { nium, formoterol, and budesonide } \\
\text { on coronavirus HCoV-229E repli- } \\
\text { cation and cytokine production by } \\
\text { primary cultures of human nasal } \\
\text { and tracheal epithelial cells }\end{array}$ & $\begin{array}{l}\text { Yamaya M; } \\
\text { Nishimura } \\
\text { H; Deng X; } \\
\text { Sugawara M; } \\
\text { Watanabe O; } \\
\text { Nomura K; } \\
\text { Shimotai Y; } \\
\text { Momma H; } \\
\text { Ichinose M; } \\
\text { Kawase T. }\end{array}$ & Netherlands & 2020 & $\begin{array}{l}\text { - Primary human nasal (HNE) and tracheal (HTE) } \\
\text { epithelial cell cultures were infected with HCoV-229E } \\
\text { coronavirus. } \\
\text { - Pretreatment of HNE and HTE cells with glycopyr- } \\
\text { ronium or formoterol decreased viral RNA levels and/ } \\
\text { or titers, the expression of the HCoV-229E recep- } \\
\text { tor CD13, the number and fluorescence intensity of } \\
\text { acidic endosomes where HCoV-229E RNA enters the } \\
\text { cytoplasm, and the infection-induced production of } \\
\text { cytokines, including IL-6, IL-8, and IFN-beta. } \\
\text { - IL-6 and IL-8 are related to airway inflammation in } \\
\text { COPD and bronchial asthma exacerbation induced } \\
\text { by viral infection. The decreased production of IL-6 } \\
\text { and IL-8 in cells pretreated with glycopyrronium, } \\
\text { formoterol, and budesonide, as well as the increased } \\
\text { inhibitory effects of GFB observed in the present } \\
\text { study, may be associated with the inhibitory effects } \\
\text { of these drugs on COPD and bronchial asthma } \\
\text { exacerbation. }\end{array}$ \\
\hline [41] & $\begin{array}{l}\text { Analysis of clinical features of } 29 \\
\text { patients with } 2019 \text { novel corona- } \\
\text { virus pneumonia }\end{array}$ & $\begin{array}{l}\text { Chen, L; Liu, } \\
\text { H G; Liu, W; } \\
\text { Liu, J; Liu, } \\
\text { K; Shang, } \\
\text { J; Deng, Y; } \\
\text { Wei, S. }\end{array}$ & China & 2020 & $\begin{array}{l}\text { - } 29 \text { patients with } 2019-\text {-ncov admitted to the isolation } \\
\text { ward of Tongji hospital ( mild (15 cases), severe (9 } \\
\text { cases) and critical ( } 5 \text { cases). } \\
\text { - The expression levels of inflammatory cytokines } \\
\text { and other markers in the serum of each group were } \\
\text { detected. } \\
\text { - There were statistically significant differences in the } \\
\text { expression levels of interleukin-2 receptor (IL-2R) } \\
\text { and IL-6 in the serum of the three groups ( } p<0.05 \text { ), } \\
\text { among which the critical group was higher than the } \\
\text { severe group and the severe group was higher than } \\
\text { the mild group. } \\
\text { - However, there were no statistically significant differ- } \\
\text { ences in serum levels of tumor necrosis factor-alpha } \\
\text { (TNF-alpha), IL-1, IL-8, IL-10, hs-CRP, lymphocyte } \\
\text { count and LDH among the three groups ( } P>0.05 \text { ). }\end{array}$ \\
\hline
\end{tabular}


Supplementary Table 4. Current studies investigating COVID-19/ other coronavirus strains and IL-6. (continued)

\begin{tabular}{|c|c|c|c|c|c|}
\hline [26] & $\begin{array}{l}\text { Severe acute respiratory syn- } \\
\text { drome: clinical and laboratory } \\
\text { manifestations. }\end{array}$ & $\begin{array}{l}\text { Lam, Chris- } \\
\text { topher W K; } \\
\text { Chan, Michael } \\
\text { H M; Wong, } \\
\text { Chun K. }\end{array}$ & Australia & 2004 & $\begin{array}{l}\text { - They have investigated daily changes in plasma } \\
\text { inflammatory cytokines and chemokines in } 20 \text { adult } \\
\text { SARS patients [19 men and } 1 \text { woman, mean (SD) age } \\
33 \text { (12) years, range } 21-58 \text { ] for } 19 \text { consecutive days } \\
\text { upon hospital admission (from } \leq 2 \text { days after disease } \\
\text { onset). } \\
\text { - The cytokine profile showed marked elevation of } \\
\text { T-helper lymphocyte type } 1 \text { (Th1) cytokine IFN- } \gamma \text {, } \\
\text { inflammatory cytokines IL-1ß, IL-6 and IL-12 for at } \\
\text { least two weeks after disease onset, but there was no } \\
\text { significant increase in inflammatory cytokine TNF-a, } \\
\text { anti-inflammatory cytokine IL-10, Th1 cytokine IL-2, } \\
\text { and T-helper lymphocyte type } 2 \text { (Th2) cytokine IL-4. } \\
\text { We have also performed serial studies of plasma cyto- } \\
\text { kine and chemokine profiles of } 8 \text { children with SARS } \\
\text { (5 boys and } 3 \text { girls, age } 0.3 \text { - } 6.2 \text { years) and found } \\
\text { that these patients had a much milder cytokine and } \\
\text { chemokine storm, rendering the use of corticosteroids } \\
\text { more controversial if not unjustified. }\end{array}$ \\
\hline [42] & $\begin{array}{l}\text { Clinical Progression and Cytokine } \\
\text { Profiles of Middle East Respira- } \\
\text { tory Syndrome Coronavirus } \\
\text { Infection. }\end{array}$ & $\begin{array}{l}\text { Kim ES; Choe } \\
\text { PG; Park WB; } \\
\text { Oh HS; Kim } \\
\text { EJ; Nam EY; } \\
\text { Na SH; Kim } \\
\text { M; Song KH; } \\
\text { Bang JH; Park } \\
\text { SW; Kim HB; } \\
\text { Kim NJ; Oh } \\
\text { MD. }\end{array}$ & Korea (South) & 2016 & $\begin{array}{l}\text { - } 17 \text { patients with laboratory-confirmed MERS-CoV } \\
\text { during the } 2015 \text { outbreak in Korea were studied. } \\
\text { - The severe group had higher neutrophil counts during } \\
\text { week } 1 \text { than the mild group ( } 4,500 \text { versus } 2,200 / \mathrm{muL} \text {, } \\
\mathrm{P}=0.026 \text { ). In the second week of illness, the severe } \\
\text { group had higher serum levels of IL-6 ( } 54 \text { versus } 4 \mathrm{pg} / \\
\mathrm{ml}, p=0.006 \text { ) and CXCL-10 (2,642 versus } 382 \mathrm{pg} / \mathrm{ml} \text {, } \\
p<0.001 \text { ). }\end{array}$ \\
\hline [27] & $\begin{array}{l}\text { Decoding the enigma of antiviral } \\
\text { crisis: Does one target molecule } \\
\text { regulate all?. [Review] }\end{array}$ & $\begin{array}{l}\text { Mahmud- } \\
\text { Al-Rafat A; } \\
\text { Majumder } \\
\text { A; Taufiqur } \\
\text { Rahman } \\
\text { KM; Mahedi } \\
\text { Hasan AM; } \\
\text { Didarul Islam } \\
\text { KM; Taylor- } \\
\text { Robinson AW; } \\
\text { Billah MM }\end{array}$ & England & 2019 & $\begin{array}{l}\text { - IL-6 Interleukin acts as a mediator between pro- and } \\
\text { anti-inflammatory reactivity by initiating trans- and } \\
\text { classical-signalling, which might relate to the cytokine } \\
\text { storm that is triggered by excessive pro-inflammatory } \\
\text { responses to Ebola, SARS-CoV and dengue infections } \\
\text { in humans. } \\
\text { - Future antivirals should thus aim to target the mecha- } \\
\text { nism that regulates switching between IL-6 trans- and } \\
\text { classical-signaling } \\
\text { - The tumour necrosis factor-a converting enzyme } \\
\text { ADAM-17 could be the master molecule involved } \\
\text { in regulating IL-6 class switching and through this in } \\
\text { controlling pro- and anti-inflammatory responses to } \\
\text { viral antigenic stimuli. } \\
\text { ADAM-17 should be considered as a potential target } \\
\text { molecule for novel antiviral drug discovery that would } \\
\text { regulate host reactivity to infection and thereby limit } \\
\text { or prevent fatal outcomes. }\end{array}$ \\
\hline
\end{tabular}


Supplementary Table 4. Current studies investigating COVID-19/ other coronavirus strains and IL-6. (continued)

\begin{tabular}{|c|c|c|c|c|c|}
\hline [43] & $\begin{array}{l}\text { Extraordinary GU-rich single- } \\
\text { strand RNA identified from SARS } \\
\text { coronavirus contributes an exces- } \\
\text { sive innate immune response. }\end{array}$ & $\begin{array}{l}\text { Li Y; Chen M; } \\
\text { Cao H; Zhu } \\
\text { Y; Zheng J; } \\
\text { Zhou H. }\end{array}$ & France & 2013 & $\begin{array}{l}\text { - They identified a set of SARS-CoV specific GU-rich } \\
\text { ssRNA fragments with a high-density distribution in } \\
\text { the genome. } \\
\text { - In vitro experiments, the result showed the repre- } \\
\text { sentative SARS-CoV ssRNAs had powerful immu- } \\
\text { nostimulatory activities to induce considerable level } \\
\text { of pro-inflammatory cytokine TNF-a, IL-6 and IL-12 } \\
\text { release via the TLR7 and TLR8, almost 2-fold higher } \\
\text { than the strong stimulatory ssRNA40 that was found } \\
\text { previously from other virus. } \\
\text { - Moreover, SARS-CoV ssRNA was able to cause acute } \\
\text { lung injury in mice with a high mortality rate in vivo } \\
\text { experiment. It suggests that SARS-CoV specific } \\
\text { GU-rich ssRNA plays a very important role in the } \\
\text { cytokine storm associated with a dysregulation of } \\
\text { the innate immunity and could open a new thera- } \\
\text { peutic strategy. }\end{array}$ \\
\hline [44] & $\begin{array}{l}\text { Regulation of the p38 mitogen- } \\
\text { activated protein kinase and } \\
\text { dual-specificity phosphatase } 1 \\
\text { feedback loop modulates the } \\
\text { induction of interleukin } 6 \text { and } 8 \\
\text { in cells infected with coronavirus } \\
\text { infectious bronchitis virus. }\end{array}$ & $\begin{array}{l}\text { Liao Y; Wang } \\
\text { X; Huang M; } \\
\text { Tam JP; Liu } \\
\text { DX }\end{array}$ & US & 2011 & $\begin{array}{l}\text { Characterised cellular mechanisms exploited by } \\
\text { coronavirus infectious bronchitis virus (IBV) to } \\
\text { regulate the induction of two pro-inflammatory } \\
\text { cytokines, interleukin (IL)- } 6 \text { and IL-8, at the tran- } \\
\text { scriptional level. } \\
\text { - IBV modulates the infection by inducing the expres- } \\
\text { sion of dual-specificity phosphatase } 1 \text { (DUSP1), a } \\
\text { negative regulator of the p38 MAPK, in order to limit } \\
\text { the production of an excessive amount of IL- } 6 \text { and } \\
\text { IL-8 in the infected cells. } \\
\text { DUSP1 and p38 MAPK are possible therapeutic } \\
\text { targets for IBV. }\end{array}$ \\
\hline [45] & $\begin{array}{l}\text { A new mouse-adapted strain of } \\
\text { SARS-CoV as a lethal model for } \\
\text { evaluating antiviral agents in vitro } \\
\text { and in vivo. }\end{array}$ & $\begin{array}{l}\text { Day CW; } \\
\text { Baric R; Cai } \\
\text { SX; Frieman } \\
\text { M; Kumaki Y; } \\
\text { Morrey JD; } \\
\text { Smee DF; } \\
\text { Barnard DL. }\end{array}$ & US & 2009 & $\begin{array}{l}\text { - A new strain of SARS-CoV (strain v2163) was char- } \\
\text { acterised and it was highly lethal in 5- to 6-week-old } \\
\text { BALB/c mice. It had nine mutations affecting } 10 \\
\text { amino acid residues. } \\
\text { Strain v2163 increased IL-1alpha, IL-6, MIP-1alpha, } \\
\text { MCP-1, and RANTES in mice, and high IL-6 expression } \\
\text { correlated with mortality. }\end{array}$ \\
\hline [46] & $\begin{array}{l}\text { Neutralising antibody against se- } \\
\text { vere acute respiratory syndrome } \\
\text {-coronavirus spike is highly effec- } \\
\text { tive for the protection of mice in } \\
\text { the murine SARS model. }\end{array}$ & $\begin{array}{l}\text { Ishii K; } \\
\text { Hasegawa } \\
\text { H; Nagata } \\
\text { N; Ami Y; } \\
\text { Fukushi S; } \\
\text { Taguchi F; } \\
\text { Tsunetsugu- } \\
\text { Yokota Y }\end{array}$ & Australia & 2009 & $\begin{array}{l}\text { - The efficacy of three SARS vaccine candidates was } \\
\text { tested in a murine SARS model utilising low-virulence } \\
\text { Pp and SARS-CoV coinfection. } \\
\text { - Vaccinated mice were protected from severe respira- } \\
\text { tory disease. } \\
\text { - A high level of IL-6 and on days } 2 \text { and } 3 \text { after SARS- } \\
\text { CoV infection was closely linked to the virus replica- } \\
\text { tion and disease severity, suggesting the importance } \\
\text { of these cytokines in the lung pathogenicity of SARS- } \\
\text { CoV infection. }\end{array}$ \\
\hline
\end{tabular}


Supplementary Table 4. Current studies investigating COVID-19/ other coronavirus strains and IL-6. (continued)

\begin{tabular}{|c|c|c|c|c|c|}
\hline [47] & $\begin{array}{l}\text { Severe acute respiratory } \\
\text { syndrome (18) coronavirus- } \\
\text { induced lung epithelial cytokines } \\
\text { exacerbate SARS pathogenesis by } \\
\text { modulating intrinsic functions of } \\
\text { monocyte-derived macrophages } \\
\text { and dendritic cells. }\end{array}$ & $\begin{array}{l}\text { Yoshikawa } \\
\text { T; Hill T; Li } \\
\text { K; Peters CJ; } \\
\text { Tseng CT. }\end{array}$ & US & 2009 & $\begin{array}{l}\text { - In highly polarised human lung epithelial Calu-3 cells } \\
\text { modelled the cellular bases of the host antiviral innate } \\
\text { immunity within the lungs. } \\
\text { - Role of IL-6 as a key SARS-CoV-induced epithelial } \\
\text { cytokine capable of inhibiting the T-cell-priming ability } \\
\text { of Denditric cells leading to an exacerbated inflam- } \\
\text { matory cascades and severe tissue damage in SARS } \\
\text { patients. }\end{array}$ \\
\hline [48] & $\begin{array}{l}\text { Nucleocapsid protein of SARS- } \\
\text { CoV activates interleukin-6 } \\
\text { expression through cellular tran- } \\
\text { scription factor NF-kappaB. }\end{array}$ & $\begin{array}{l}\text { Zhang X; Wu } \\
\text { K; Wang D; } \\
\text { Yue X; Song } \\
\text { D; Zhu Y; } \\
\text { Wu J. }\end{array}$ & US & 2007 & $\begin{array}{l}\text { - High levels of IL6 High levels of interleukin-6 (IL-6) } \\
\text { in the acute stage associated with lung lesions were } \\
\text { found in SARS patients. } \\
\text { - The viral nucleocapsid SARS-CoV N protein activate } \\
\text { IL-6 expression in the lung cells. }\end{array}$ \\
\hline [49] & $\begin{array}{l}\text { Cytokine regulation in SARS } \\
\text { coronavirus infection compared to } \\
\text { other respiratory virus infections. }\end{array}$ & $\begin{array}{l}\text { Okabayashi } \\
\text { T; Kariwa H; } \\
\text { Yokota S; Iki } \\
\text { S; Indoh T; } \\
\text { Yokosawa N; } \\
\text { Takashima I; } \\
\text { Tsutsumi H; } \\
\text { Fujii N. }\end{array}$ & US & 2006 & $\begin{array}{l}\text { - They compared the cytokine profile in Caco2 cells } \\
\text { after infection of SARS coronavirus (SARS-CoV) with } \\
\text { other respiratory viruses including respiratory syncy- } \\
\text { tial virus (RSV), influenza A virus (FluAV), and human } \\
\text { parainfluenza virus type } 2 \text { (hPIV2). } \\
\text { - Interferon (IFN) system (production and response) was } \\
\text { not suppressed by SARS-CoV infection } \\
\text { - SARS-CoV and RSV induced high levels of IL-6 and } \\
\text { RANTES compared with FluAV and hPIV2. } \\
\text { - Induction level of suppressor of cytokine signaling-3 } \\
\text { (SOCS3) by SARS-CoV was significantly lower than } \\
\text { that by RSV in spite of the significant production of } \\
\text { IL-6. } \\
\text { - Collectively, overinduction of inflammatory cytokine } \\
\text { and dysregulation of cytokine signaling may contrib- } \\
\text { ute to the immunopathology associated with "severe" } \\
\text { inflammation in SARS. }\end{array}$ \\
\hline [31] & $\begin{array}{l}\text { A study of pulmonary inflammato- } \\
\text { ry reaction induced by } N \text {-protein } \\
\text { of SARS-CoV in rat models and } \\
\text { effects of glucocorticoids on it }\end{array}$ & $\begin{array}{l}\text { Hao D; He } \\
\text { LX; Qu JM; } \\
\text { Pan J; Hu BJ; } \\
\text { Zhang J; Li } \\
\text { ZZ. }\end{array}$ & China & 2005 & $\begin{array}{l}\text { The pulmonary inflammatory reaction in rat models } \\
\text { were induced by intratracheal instillation of N-protein } \\
\text { of SARS-CoV and glucocorticoids were administrated } \\
\text { to one of the groups. } \\
\text { - The N-protein of SARS-CoV presented pathogenicity } \\
\text { and could induce pulmonary inflammatory reaction } \\
\text { and acute lung injury, which were related to the } \\
\text { increase and imbalance of pro-inflammatory and } \\
\text { anti-inflammatory cytokines. Glucocorticoids could } \\
\text { effectively alleviate the pulmonary inflammatory reac- } \\
\text { tion induced by N-protein of SARS-CoV. }\end{array}$ \\
\hline [50] & $\begin{array}{l}\text { Clinical manifestations and } \\
\text { inflammatory cytokine responses } \\
\text { in patients with severe acute } \\
\text { respiratory syndrome. }\end{array}$ & $\begin{array}{l}\text { Sheng WH; } \\
\text { Chiang BL; } \\
\text { Chang SC; Ho } \\
\text { HN; Wang } \\
\text { JT; Chen YC; } \\
\text { Hsiao CH; } \\
\text { Hseuh PR; } \\
\text { Chie WC; } \\
\text { Yang PC. }\end{array}$ & Singapore & 2005 & $\begin{array}{l}\text { - Fourteen hospitalised patients with a diagnosis of } \\
\text { SARS-associated coronavirus infection. } \\
\text { - There were no significant differences in peak levels of } \\
\text { IL-6, IL-8 and TNF-alpha between patients with and } \\
\text { without acute respiratory distress syndrome. } \\
\text { - CRP and TNF-alpha are associated with worse out- } \\
\text { comes and might be used as prognostic markers of } \\
\text { SARS. }\end{array}$ \\
\hline
\end{tabular}


Supplementary Table 4. Current studies investigating COVID-19/ other coronavirus strains and IL-6. (continued)

\begin{tabular}{|c|c|c|c|c|c|}
\hline [51] & $\begin{array}{l}\text { Severe acute respiratory syn- } \\
\text { drome and the innate immune } \\
\text { responses: modulation of effector } \\
\text { cell function without productive } \\
\text { infection. }\end{array}$ & $\begin{array}{l}\text { Tseng CT; } \\
\text { Perrone } \\
\text { LA; Zhu H; } \\
\text { Makino S; } \\
\text { Peters CJ. }\end{array}$ & US & 2005 & $\begin{array}{l}\text { - SARS-CoV does not productively infect human macro- } \\
\text { phages or Dentritic cells, it appears to exert differen- } \\
\text { tial effects on Mphi and DC maturation and functions, } \\
\text { which might contribute to SARS pathogenesis. } \\
\text { - It modulates a massive release of IL-6 and IL-12. } \\
\text { However, the endocytic capacity (e.g., Ag capture) of } \\
\text { Mphi was significantly compromised upon exposure to } \\
\text { infectious SARS-CoV. }\end{array}$ \\
\hline [52] & $\begin{array}{l}\text { An interferon-gamma-related } \\
\text { cytokine storm in SARS patients. }\end{array}$ & $\begin{array}{l}\text { Huang KJ; Su } \\
\text { IJ; Theron M; } \\
\text { Wu YC; Lai } \\
\text { SK; Liu CC; } \\
\text { Lei HY. }\end{array}$ & US & 2005 & $\begin{array}{l}\text { - Fourteen cytokines or chemokines were analysed } \\
\text { on } 88 \text { RT-PCR-confirmed severe acute respiratory } \\
\text { syndrome [18] patients. } \\
\text { - IFN-gamma, IL-18, TGF-beta, IL-6, IP-10, MCP-1, MIG, } \\
\text { and IL-8, but not of TNF-alpha, IL-2, IL-4, IL-10, IL-13, } \\
\text { or TNFRI, were highly elevated in the acute phase sera } \\
\text { of Taiwan SARS patients. } \\
\text { - IL-18, IP-10, MIG, and MCP-1 were significantly } \\
\text { higher in the death group than in the survival group } \\
\text { - An interferon-gamma-related cytokine storm was } \\
\text { induced post SARS coronavirus infection, and this } \\
\text { cytokine storm might be involved in the immunopath- } \\
\text { ological damage in SARS patients. }\end{array}$ \\
\hline [53] & $\begin{array}{l}\text { Temporal relationship of viral load, } \\
\text { ribavirin, interleukin (IL)- } 6 \text {, IL-8, } \\
\text { and clinical progression in patients } \\
\text { with severe acute respiratory } \\
\text { syndrome. }\end{array}$ & $\begin{array}{l}\text { Wang WK; } \\
\text { Chen SY; Liu } \\
\text { IJ; Kao CL; } \\
\text { Chen HL; Chi- } \\
\text { ang BL; Wang } \\
\text { JT; Sheng } \\
\text { WH; Hsueh } \\
\text { PR; Yang CF; } \\
\text { Yang PC; } \\
\text { Chang SC; }\end{array}$ & US & 2004 & $\begin{array}{l}\text { - } 8 \text { patients with acute respiratory syndrome [18], were } \\
\text { included to study the link between viral load, ribavirin, } \\
\text { proinflammatory cytokines, and clinical progression. } \\
\text { - ribavirin was not effective in reducing the SARS coro- } \\
\text { navirus load in } 3 \text { of } 8 \text { probable cases studied } \\
\text { - elevated levels of interleukin (IL)- } 6 \text { and IL-8 subse- } \\
\text { quent to the peak viral load were found in } 8 \text { and } 6 \\
\text { cases, respectively. }\end{array}$ \\
\hline [54] & $\begin{array}{l}\text { Analysis of serum cytokines in } \\
\text { patients with severe acute respi- } \\
\text { ratory syndrome. }\end{array}$ & $\begin{array}{l}\text { Zhang Y; Li J; } \\
\text { Zhan Y; Wu L; } \\
\text { Yu X; Zhang } \\
\text { W; Ye L; Xu S; } \\
\text { Sun R; Wang } \\
\text { Y; Lou J. }\end{array}$ & US & 2004 & $\begin{array}{l}\text { - Serum from } 110 \text { individuals (healthy donors, patients } \\
\text { with SARS, patients with severe SARS, and patients } \\
\text { with SARS in convalescence) was collected and cyto- } \\
\text { kine profile was studied. } \\
\text { - The IL-6 concentration was increased in SARS patients } \\
\text { and was significantly elevated in severe SARS patients, } \\
\text { but the IL-6 concentrations were similar in convales- } \\
\text { cent patients and control subjects, suggesting that } \\
\text { there was a positive relationship between the serum } \\
\text { IL-6 concentration and } \\
\text { - SARS severity. } \\
\text { - The concentrations of IL-8 and TGF-beta were } \\
\text { decreased in SARS patients and significantly reduced } \\
\text { in severe SARS patients, but they were comparable } \\
\text { in convalescent SARS patients and control subjects, } \\
\text { suggesting that there was a negative relationship } \\
\text { between the IL-8 and TGF-beta concentrations and } \\
\text { SARS severity. } \\
\text { - The concentrations of IL-1 and TNF-alpha were not } \\
\text { significantly different in different groups. }\end{array}$ \\
\hline
\end{tabular}


Supplementary Table 4. Current studies investigating COVID-19/ other coronavirus strains and IL-6. (continued)

\begin{tabular}{|c|c|c|c|c|c|}
\hline [34] & $\begin{array}{l}\text { Plasma inflammatory cytokines } \\
\text { and chemokines in severe acute } \\
\text { respiratory syndrome. }\end{array}$ & $\begin{array}{l}\text { Wong CK; } \\
\text { Lam CW; Wu } \\
\text { AK; Ip WK; } \\
\text { Lee NL; Chan } \\
\text { IH; Lit LC; } \\
\text { Hui DS; Chan } \\
\text { MH; Chung } \\
\text { SS; Sung JJ. }\end{array}$ & England & 2004 & $\begin{array}{l}\text { - Changes in plasma T helper (Th) cell cytokines, inflam- } \\
\text { matory cytokines and chemokines in } 20 \text { patients } \\
\text { diagnosed with SARS were assessed. } \\
\text { - Th1 cytokine interferon (IFN)-gamma, inflamma- } \\
\text { tory cytokines interleukin (IL)-1, IL-6 and IL-12 was } \\
\text { elevated for at least } 2 \text { weeks after disease onset, but } \\
\text { there was no significant elevation of inflammatory } \\
\text { cytokine tumour necrosis factor (TNF)-alpha, anti- } \\
\text { inflammatory cytokine IL-10, Th1 cytokine IL-2 and } \\
\text { Th2 cytokine IL-4. } \\
\text { - The chemokine profile demonstrated significant eleva- } \\
\text { tion of neutrophil chemokine IL-8, monocyte che- } \\
\text { moattractant protein-1 (MCP-1), and Th1 chemokine } \\
\text { IFN-gamma-inducible protein-10 (IP-10). } \\
\text { - Corticosteroid reduced significantly IL-8, MCP-1 and } \\
\text { IP-10 concentrations from } 5 \text { to } 8 \text { days after treatment } \\
\text { (all } p<0.001 \text { ). }\end{array}$ \\
\hline [55] & $\begin{array}{l}\text { Dynamic changes and the mean- } \\
\text { ings of blood cytokines in severe } \\
\text { acute respiratory syndrome }\end{array}$ & $\begin{array}{l}\text { Wang and } \\
\text { Pang }\end{array}$ & China & 2003 & $\begin{array}{l}\text { - (Abstract only) } \\
\text { - This study observed changed in various serum IL lev- } \\
\text { els in patients with SARS. The authors stated that the } \\
\text { mean concentration of serum IL-6 in SARS patients } \\
\text { did not differ from the control group in 3-7-day group } \\
\text { and 8-14-day group, but became significantly higher } \\
\text { in over 14-day group as compared to the control } \\
\text { group, 3-7-day group and 8-14-day group ( } p<0.01 \text { ). } \\
\text { The results of the study led the authors to conclude } \\
\text { that the immune state of SARS was abnormal. How- } \\
\text { ever, as only the abstract was available it is hard to } \\
\text { draw upon any more conclusions from this study in } \\
\text { relation in IL-6 specifically. }\end{array}$ \\
\hline [56] & $\begin{array}{l}\text { Inflammatory Cytokine Profile } \\
\text { in Children With Severe Acute } \\
\text { Respiratory Syndrome }\end{array}$ & $\mathrm{Ng}$ et al & Hong Kong & 2004 & $\begin{array}{l}\text { The authors of this study set out to study the inflam- } \\
\text { matory cytokine profile in children with SARS. They } \\
\text { found that the plasma concentrations key proinflam- } \\
\text { matory cytokines, including IL-6 were not substan- } \\
\text { tially increased in any of the patients throughout the } \\
\text { course of illness. From this the authors stated that the } \\
\text { cytokine results cast doubt on the liberal use of cor- } \\
\text { ticosteroids in paediatric SARS patients, as the host } \\
\text { immunologic response did not seem to be as severe as } \\
\text { initially anticipated. }\end{array}$ \\
\hline
\end{tabular}


Supplementary Table 5. Current studies investigating COVID-19/ other coronavirus strains and JAK inhibitors

\begin{tabular}{|c|c|c|c|c|c|}
\hline Study Ref & Title & Authors & $\begin{array}{l}\text { Country of } \\
\text { study }\end{array}$ & Year & Summary of results \\
\hline [57] & $\begin{array}{l}\text { Baricitinib as potential treatment } \\
\text { for } 2019-\mathrm{nCoV} \text { acute respiratory } \\
\text { disease }\end{array}$ & $\begin{array}{l}\text { Richardson } \\
\text { et al }\end{array}$ & England & 2020 & $\begin{array}{l}\text { - ACE2 is a cell-surface protein on lung cells in corona } \\
\text { viral infected patients } \\
\text { - AAK1 receptor promoted endocytosis involved in } \\
\text { ACE2 } \\
\text { - The study suggests the use of Baricitinib to inhibit } \\
\text { AAK1 in patients with 2019-nCoV acute respira- } \\
\text { tory disease, to reduce both the viral entry and the } \\
\text { inflammation in patients, using endpoints such as the } \\
\text { MuLBSTA score, an early warning model for predicting } \\
\text { mortality in viral pneumonia [58]. }\end{array}$ \\
\hline [59] & $\begin{array}{l}\text { The Coronavirus Transmissible } \\
\text { Gastroenteritis Virus Evades } \\
\text { the Type I Interferon Response } \\
\text { through IRE1a-Mediated Manipu- } \\
\text { lation of the MicroRNA miR-30a- } \\
\text { 5p/SOCS1/3 Axis }\end{array}$ & Ma et al & China & 2018 & $\begin{array}{l}\text { - JAK-signal transducer and activator of transcription } \\
\text { (STAT), the suppressor of cytokine signaling protein } 1 \\
\text { (SOCS1), and SOCS3. } \\
\text { - IFN-I are major antiviral molecules, and coronaviruses } \\
\text { have evolved diverse strategies to counter the IFN-I } \\
\text { response during infection. } \\
\text { - This study uses endoplasmic reticulum stress and } \\
\text { IFN-I production after infection with transmissible } \\
\text { gastroenteritis virus (TGEV) to understand how coro- } \\
\text { navirus-elicited ER stress is actively involved in viral } \\
\text { replication and manipulates the host IFN-I response. } \\
\text { - Increased SOCS1 or SOCS3 expression impaired the } \\
\text { IFN-I antiviral response, promoting TGEV replication. } \\
\text { - IRE1a is an endoplasmic reticulum stress sensor, } \\
\text { which led to the increased expression of negative } \\
\text { regulators of JAK-STAT SOCS1 and SOCS3. } \\
\text { - Therefore, IRE1a may be a novel target against coro- } \\
\text { navirus infection. }\end{array}$ \\
\hline$[60]$ & $\begin{array}{l}\text { Targeting Coronaviral Replica- } \\
\text { tion and Cellular JAK2 Mediated } \\
\text { Dominant NF-kappaB Activation } \\
\text { for Comprehensive and Ultimate } \\
\text { Inhibition of Coronaviral Activity }\end{array}$ & Yang et al & Taiwan & 2017 & $\begin{array}{l}\text { - Tylophorine-based compounds exert broad spectral, } \\
\text { potent inhibition of coronaviruses. } \\
\text { - NF-kB activation is a common pro-inflammatory } \\
\text { response of host cells to viral infection. } \\
\text { - The combination treatment, wherein a tylophorine } \\
\text { compound targets TGEV and a JAK2 inhibitor blocks } \\
\text { the alternative dominant NF-KB activation mediated } \\
\text { by JAK2, is more effective and comprehensive than } \\
\text { either one alone and constitutes a feasible approach } \\
\text { for the treatment of SARS-CoV or MERS-CoV }\end{array}$ \\
\hline [61] & $\begin{array}{l}\text { Severe Acute Respiratory } \\
\text { Syndrome Coronavirus Evades } \\
\text { Antiviral Signaling: Role of nsp1 } \\
\text { and Rational Design of an Attenu- } \\
\text { ated Strain }\end{array}$ & Wathelet et al & USA & 2007 & $\begin{array}{l}\text { Expression of non-structural protein } 1 \text { (nsp1) signifi- } \\
\text { cantly inhibited the activation of SARS-Cov signaling } \\
\text { pathways. } \\
\text { - However, the study results show that SARS-CoV nsp1 } \\
\text { does not inhibit JAK phosphorylation. }\end{array}$ \\
\hline
\end{tabular}


Supplementary Table 6. Current studies investigating COVID-19/ other coronavirus strains and IL-1 blockade.

\begin{tabular}{|c|c|c|c|c|c|}
\hline Study Ref & Title & Authors & $\begin{array}{c}\text { Country of } \\
\text { study }\end{array}$ & Year & Summary of results \\
\hline$[62]$ & $\begin{array}{l}\text { Analysis of clinical features of } 29 \\
\text { patients with } 2019 \text { novel corona- } \\
\text { virus pneumonia. }\end{array}$ & Chen et al & China & 2020 & $\begin{array}{l}\text { The levels of several inflammatory markers were } \\
\text { measured in } 29 \text { COVID-19 patients and were compared } \\
\text { between general, severe and critically ill groups. The } \\
\text { authors reported no significant differences in IL-1b levels } \\
\text { between the three groups of patients. }\end{array}$ \\
\hline [63] & $\begin{array}{l}\text { Rat coronaviruses infect rat } \\
\text { alveolar type I epithelial cells } \\
\text { and induce expression of CXC } \\
\text { chemokines. }\end{array}$ & Miura et al & USA & 2007 & $\begin{array}{l}\text { The authors used two rat coronaviruses on alveolar } \\
\text { epithelial cells taken from } 6-8 \text { weeks old rats. Infection } \\
\text { with the viruses caused the increase in expressed of } \\
\text { both IL-1a and IL-1b. The authors concluded that the } \\
\text { virus-induced chemokine expression was subsequently } \\
\text { reduced by the IL-1 receptor antagonist, suggesting that } \\
\text { IL-1 produced by infected cells induces uninfected cells } \\
\text { to express chemokines. }\end{array}$ \\
\hline [64] & $\begin{array}{l}\text { Role of the inflammasome-related } \\
\text { cytokines II-1 and II-18 during } \\
\text { infection with murine coronavirus. }\end{array}$ & $\begin{array}{l}\text { Zalinger, } \\
\text { Elliott and } \\
\text { Weiss }\end{array}$ & USA & 2017 & $\begin{array}{l}\text { The authors used several infectious agents including } \\
\text { murine coronavirus to assess the role of the inflamma- } \\
\text { some and its related cytokines on pathogenesis and host } \\
\text { defence during viral infection. The authors concluded } \\
\text { that mice lacking IL-1 signalling experienced elevated } \\
\text { viral replication but similar survival compared to wild- } \\
\text { type controls. }\end{array}$ \\
\hline [65] & $\begin{array}{l}\text { Severe Acute Respiratory } \\
\text { Syndrome Coronavirus Viroporin } \\
\text { 3a Activates the NLRP3 } \\
\text { Inflammasome. }\end{array}$ & Chen et al & $\begin{array}{l}\text { Japan and } \\
\text { Taiwan }\end{array}$ & 2019 & $\begin{array}{l}\text { The authors provide evidence that SARS-CoV 3a protein } \\
\text { activates the NLRP3 inflammasome in lipopolysaccha- } \\
\text { ride-primed macrophages and that the ion channel activ- } \\
\text { ity of the } 3 \text { a protein was essential for 3a-mediated IL-1 } \beta \\
\text { secretion. The macrophages obtained in this study were } \\
\text { from 6-week-old female mice. }\end{array}$ \\
\hline [66] & $\begin{array}{l}\text { Mast cells contribute } \\
\text { to coronavirus-induced } \\
\text { inflammation: new anti- } \\
\text { inflammatory strategy. }\end{array}$ & Kritas et al & $\begin{array}{l}\text { Greece, Italy } \\
\text { and USA }\end{array}$ & 2020 & $\begin{array}{l}\text { (Abstract Only) } \\
\text { Infection with coronavirus activates mast cells which in } \\
\text { turn causes the generation of pro-inflammatory IL-1 fam- } \\
\text { ily members. The authors state that they demonstrate } \\
\text { for the first time that inflammation by coronavirus may } \\
\text { be inhibited by anti-inflammatory cytokines belonging to } \\
\text { the IL-1 family. However, as this is only an abstract there } \\
\text { is no further information to support this statement. }\end{array}$ \\
\hline
\end{tabular}


Supplementary Table 6. Current studies investigating COVID-19/ other coronavirus strains and IL-1 blockade. (continued)

\begin{tabular}{|c|c|c|c|c|c|}
\hline [67] & SARS Immunity and Vaccination. & Zhu M & China & 2004 & $\begin{array}{l}\text { SARS-CoV binds to host cells via a specific SARS recep- } \\
\text { tor, angiotensin converting enzyme } 2 \text { (ACE-2). } \\
\text { Following entry into the cell, the virus uncoats, nucleic } \\
\text { acid is released and transcription occurs for production } \\
\text { of viral proteins. During this course, the host immune } \\
\text { system is activated (B and T-cells). } \\
\text { Specifically, CD4+ T helper cells recognise antigenic pep- } \\
\text { tides produced by antigen presenting cells and produce } \\
\text { cytokines that promote cell mediated and/or humoral } \\
\text { immunity. } \\
\text { Similarly to avian flu, SARS infection induced similar pro- } \\
\text { inflammatory cytokine pattern and might contribute to } \\
\text { the severe nature of the virus. } \\
\text { Clinical evidence of SARS treatment by corticosteroids } \\
\text { where levels of IL-1beta reduced after administration- } \\
\text { thus inhibition of inflammatory cytokines such as IL-1 } \\
\text { may be beneficial strategy for treatment of SARS. }\end{array}$ \\
\hline [54] & $\begin{array}{l}\text { Analysis of serum cytokines in } \\
\text { patients with severe acute respi- } \\
\text { ratory syndrome. }\end{array}$ & $\begin{array}{l}\text { Zhang Y, Li J, } \\
\text { Zhan Y, Wu L, } \\
\text { Yu X, Zhang } \\
\text { W, Ye L, Xu S, } \\
\text { Sun R, Wang } \\
\text { Y, Lou J }\end{array}$ & China & 2004 & $\begin{array}{l}\text { Following the discovery of SARS-CoV, no specific or ef- } \\
\text { ficient clinical treatments were available since pathogen- } \\
\text { esis was not well understood. } \\
\text { Acute lung injury associated with SARS can be attributed } \\
\text { to complex and multifactorial pathophysiological process } \\
\text { involving cytokines. Demonstrated that IL-1 play key role } \\
\text { in pathogenesis of acute lung injury. WHO inferred that } \\
\text { severe immune response kills SARS patients and that } \\
\text { some cytokines may play important role in the process. } \\
\text { IL-1 cytokine promotes inflammation by inducing cell } \\
\text { injury. } \\
\text { Study measured levels of IL-1 in } 4 \text { patient groups: con- } \\
\text { trols, patients with SARS, patients with severe SARS and } \\
\text { convalescent SARS patients. } \\
\text { Study showed that levels of IL-1alpha did not differ } \\
\text { between } 3 \text { SARS groups or controls. } \\
\text { Suggests that host immune response to novel coronavi- } \\
\text { rus may be different from the immune reaction to other } \\
\text { pathogens. } \\
\text { Overall results suggest that acute lung injury associated } \\
\text { with SARS may not be induced by circulating cytokines. } \\
\text { HOWEVER some patients had accepted corticosteroids } \\
\text { and therefore results consistent with reports that only } \\
\text { long term treatment (7-10 days) with a steroid can alter } \\
\text { serum cytokine levels. }\end{array}$ \\
\hline
\end{tabular}


Supplementary Table 6. Current studies investigating COVID-19/ other coronavirus strains and IL-1 blockade. (continued)

\begin{tabular}{|c|c|c|c|c|c|}
\hline [34] & $\begin{array}{l}\text { Plasma inflammatory cytokines } \\
\text { and chemokines in severe acute } \\
\text { respiratory syndrome. }\end{array}$ & $\begin{array}{l}\text { Wong CK, } \\
\text { Lam CW, Wu } \\
\text { AK, Ip WK, } \\
\text { Lee NL, Chan } \\
\text { IH, Lit LC, Hui } \\
\text { DS, Chan MH, } \\
\text { Chung SS, } \\
\text { Sung JJ }\end{array}$ & Hong Kong & 2004 & $\begin{array}{l}\text { Known that over-expression of IL-1beta hallmark of } \\
\text { SARS infection probably through activation of transcrip- } \\
\text { tion factor nuclear factor, activator protein AP1 and } \\
\text { activating factor } 2 \text {. Therefore lung damage associated } \\
\text { with SARS postulated to occur through cytokine and } \\
\text { chemokine dysregulation. } \\
\text { Study involved measurement of cytokines and che- } \\
\text { mokines including IL-1beta in } 20 \text { consecutive patients } \\
\text { admitted to Hong Kong hospital. } \\
\text { IL-1beta was significantly elevated above normal range } \\
\text { within first } 12,7 \text { and } 5 \text { days after disease onset. } \\
\text { Those patients with more severe disease treated with } \\
\text { pulsed methylprednisolone. IL-1beta levels higher in } \\
\text { this patient group particularly } 3-10 \text { days after onset but } \\
\text { returned to normal levels } 1 \text { week after disease onset in } \\
\text { both sets of patients. } \\
\text { IL-1beta can act as early response cytokine to viral infection. } \\
\text { IL-1 elevation in SARS can induce hyperinnate inflamma- } \\
\text { tory response leading to recruitment and accumulation } \\
\text { of alveolar macrophages and PMN. } \\
\text { Higher disease severity associated with more elevated } \\
\text { plasma IL-1beta and addition of pulsed steroid controlled } \\
\text { rapidly deteriorating clinical condition and attenuated } \\
\text { otherwise exaggerated immunological response. }\end{array}$ \\
\hline
\end{tabular}

Supplementary Table 7. Current studies investigating COVID-19/ other coronavirus strains and Mycophenolate.

\begin{tabular}{|c|l|l|l|l|l|}
\hline Study Ref & \multicolumn{1}{|c|}{ Title } & Authors & \multicolumn{1}{c|}{$\begin{array}{c}\text { Country of } \\
\text { study }\end{array}$} & Year & \multicolumn{1}{c|}{ Summary of results } \\
\hline$[68]$ & $\begin{array}{l}\text { Interferon- } \beta \text { and mycophenolic } \\
\text { acid are potent inhibitors of } \\
\text { middle east respiratory syndrome } \\
\text { coronavirus in cell-based assays }\end{array}$ & Hart et al & USA & 2014 & $\begin{array}{l}\text { (In vitro only) } \\
\text { MPA showed strong inhibition, with an IC50 of 2.87 } \\
\text { mM. This drug may provide an alternative to ribavirin for } \\
\text { treatment of MERS-CoV. In conclusion, IFN-b, MPA or } \\
\text { a combination of the two may be beneficial in the treat- } \\
\text { ment of MERS-CoV or as a post-exposure intervention in } \\
\text { high-risk patients with known exposures to MERS-CoV. }\end{array}$ \\
\hline$[69]$ & $\begin{array}{l}\text { Disulfiram can inhibit MERS and } \\
\text { SARS coronavirus papain-like } \\
\text { proteases via different modes }\end{array}$ & Lin et al & Taiwan & 2018 & $\begin{array}{l}\text { (In vitro) } \\
\text { Note. (PLpros)= Papain-like proteases MERS-CoV and } \\
\text { SARS-CoV - act as a potential anti-viral target for drugs } \\
\text { Multiple inhibition assays also support a kinetic mecha- } \\
\text { nism by which disulfiram together with 6TG and/or MPA } \\
\text { can synergistically inhibit MERS-CoV PLpro, but not, due } \\
\text { to its competitive mode of inhibition, SARS-CoV PLpro. } \\
\text { Synergistic inhibition of MERS-CoV PLpro by disulfiram } \\
\text { and 6-thioguanine or mycophenolic acid implies the } \\
\text { potential for combination treatments using these three } \\
\text { clinically available drugs. }\end{array}$ \\
\hline
\end{tabular}


Supplementary Table 7. Current studies investigating COVID-19/ other coronavirus strains and Mycophenolate. (continued)

\begin{tabular}{|c|c|c|c|c|c|}
\hline [70] & $\begin{array}{l}\text { Thiopurine analogs and my- } \\
\text { cophenolic acid synergistically } \\
\text { inhibit the papain-like protease of } \\
\text { Middle East respiratory syndrome } \\
\text { coronavirus }\end{array}$ & Cheng et al & Taiwan & 2015 & $\begin{array}{l}\text { (In vitro) } \\
\text { At the time of the study, there were no potent inhibitors } \\
\text { that target MERS-CoV PLpro. The authors report that the } \\
\text { immunosuppressive drug mycophenolic acid, was able to } \\
\text { inhibit MERS-CoV PLpro. } \\
\text { MPA is a non-competitive inhibitor of MERS-CoV PLpro. }\end{array}$ \\
\hline [71] & $\begin{array}{l}\text { Broad-spectrum antivirals for the } \\
\text { emerging Middle East respiratory } \\
\text { syndrome coronavirus }\end{array}$ & Chan et al & $\begin{array}{l}\text { Hong Kong/ } \\
\text { China }\end{array}$ & 2013 & $\begin{array}{l}\text { (In vitro) } \\
\text { The authors assessed the anti-MERS-CoV activities of } \\
\text { several compounds. Only mycophenolic acid exhibited } \\
\text { low EC } 50 \text { and high selectivity index. } \\
\text { They found that a combination of mycophenolic acid and } \\
\text { IFN-b1b lowered the EC } 50 \text { of each drug by 1-3 times. } \\
\text { Mycophenolic acid exhibits a number of attributes that } \\
\text { support its practical use in MERS-CoV infection. It is } \\
\text { commonly available in two forms, the prodrug mycophe- } \\
\text { nolate mofetil and the salt mycophenolate sodium, and } \\
\text { could be given orally. } \\
\text { Interferon-b1b with mycophenolic acid should be consid- } \\
\text { ered in treatment trials of MERS. }\end{array}$ \\
\hline [72] & $\begin{array}{l}\text { High-Throughput Screening and } \\
\text { Identification of Potent Broad- } \\
\text { Spectrum Inhibitors of Coronavi- } \\
\text { ruses. }\end{array}$ & Shen et al & China & 2019 & $\begin{array}{l}\text { (In vitro) } \\
\text { The authors sought to identify potent broad-spectrum } \\
\text { inhibitors of corona viruses. They concluded that they } \\
\text { had identified seven compounds (lycorine, emetine, mo- } \\
\text { nensin sodium, mycophenolate mofetil, mycophenolic } \\
\text { acid, phenazopyridine, and pyrvinium pamoate) as broad- } \\
\text { spectrum inhibitors according to their strong inhibition } \\
\text { of replication by four CoVs in vitro at low-micromolar } \\
\text { concentrations. They all inhibited the replication of all } \\
\text { CoVs with EC50 values of } 5 \mu \text { m. } \\
\text { Mycophenolate mofetil and mycophenolic acid, showed } \\
\text { a similar antiviral effect on the four CoVs suggesting that } \\
\text { the two drugs might harbour similar core structures and } \\
\text { antiviral mechanisms. } \\
\text { In vivo antiviral activity is unknown from this study. }\end{array}$ \\
\hline [73] & $\begin{array}{l}\text { Glycyrrhizin, an active component } \\
\text { of liquorice roots, and replication } \\
\text { of SARS-associated coronavirus }\end{array}$ & Cinatl et al & Germany & 2003 & $\begin{array}{l}\text { (In vitro but using clinical samples - Abstract only) } \\
\text { The authors assessed the antiviral activities of ribavirin, } \\
\text { 6-azauridine, pyrazofurin, mycophenolic acid, and glycyr- } \\
\text { rhizin against two clinical isolates of coronavirus (FFM-1 } \\
\text { and FFM-2) from patients with SARS admitted to the } \\
\text { clinical centre of Frankfurt University, Germany. } \\
\text { Mycophenolic acid did not affect replication of the SARS- } \\
\text { associated coronaviruses. }\end{array}$ \\
\hline
\end{tabular}


Supplementary Table 7. Current studies investigating COVID-19/ other coronavirus strains and Mycophenolate. (continued)

\begin{tabular}{|c|c|c|c|c|c|}
\hline [74] & $\begin{array}{l}\text { Treatment outcomes for patients } \\
\text { with Middle Eastern Respiratory } \\
\text { Syndrome Coronavirus (MERS } \\
\text { CoV) infection at a coronavirus } \\
\text { referral center in the Kingdom of } \\
\text { Saudi Arabia. }\end{array}$ & $\begin{array}{l}\text { Al Ghamdi } \\
\text { et al }\end{array}$ & Saudi Arabia & 2016 & $\begin{array}{l}\text { (Clinical example) } \\
\text { Eight patients (15.7\%) received mycophenolate mofetil, } \\
\text { seven of these patients received it in combination with } \\
\text { interferon beta. All patients who received mycopheno- } \\
\text { late mofetil survived. The authors concluded that whilst } \\
\text { treatment with beta interferon and mycophenolate } \\
\text { mofetil predicted survival (in univariate analysis only), the } \\
\text { greatest predictor of survival was the severity of illness } \\
\text { on presentation. }\end{array}$ \\
\hline [75] & $\begin{array}{l}\text { Treatment with lopinavir/ritonavir } \\
\text { or interferon-beta1b improves } \\
\text { outcome of MERSCoV infection } \\
\text { in a nonhuman primate model of } \\
\text { common marmoset }\end{array}$ & Chan et al & $\begin{array}{l}\text { Hong Kong/ } \\
\text { China }\end{array}$ & 2015 & $\begin{array}{l}\text { (In vivo) } \\
\text { The authors assessed } 3 \text { repurposed drugs with potent } \\
\text { in vitro anti-MERS-CoV activity (mycophenolate mofetil, } \\
\text { lopinavir/ritonavir, and interferon- } \beta 1 \text { b) in common mar- } \\
\text { mosets with severe disease resembling MERS in humans. } \\
\text { all MMF-treated animals developed severe and/or fatal } \\
\text { disease with higher mean viral loads. } \\
\text { The authors concluded that MMF alone may worsen } \\
\text { MERS and should not be used. }\end{array}$ \\
\hline [76] & $\begin{array}{l}\text { Enhancement of the infectivity of } \\
\text { SARS-CoV in BALB/c mice by IMP } \\
\text { dehydrogenase inhibitors, includ- } \\
\text { ing ribavirin }\end{array}$ & Barnard et al & USA & 2006 & $\begin{array}{l}\text { In vivo study in BALB/c mice (a replication model for } \\
\text { SARS infections) } \\
\text { In mycophenolic acid-treated mice, the lung virus } \\
\text { titers (aka viral load) increased with increasing dosage, } \\
\text { although these increases in lung virus titers were not } \\
\text { quite significantly different from the lung virus titers in } \\
\text { placebo-treated, infected mice. }\end{array}$ \\
\hline [77] & $\begin{array}{l}\text { A review of treatment modali- } \\
\text { ties for Middle East Respiratory } \\
\text { Syndrome }\end{array}$ & Mo and Fisher & Singapore & 2016 & $\begin{array}{l}\text { (Review) } \\
\text { Mycophenolic acid also inhibits purine nucleotide syn- } \\
\text { thesis in lymphocytes. This makes it a popular immuno- } \\
\text { suppressant in solid-organ transplants and autoimmune } \\
\text { diseases such as systemic lupus erythematosus. } \\
\text { The use of mycophenolic acid monotherapy has not } \\
\text { been reported in MERS. IFN-b and mycophenolic acid } \\
\text { combination therapy was described in a retrospective } \\
\text { observational study in Saudi Arabia involving } 51 \text { patients; } \\
\text { all of the } 8 \text { patients who received IFN-b and mycopheno- } \\
\text { lic acid survived. } \\
\text { Corticosteroids, ribavirin monotherapy and mycophenolic } \\
\text { acid are likely to cause more harm than benefit. } \\
\text { There are no clinical data on the efficacy of mycopheno- } \\
\text { lic acid in SARS or MERS. However, it led to severe and/ } \\
\text { or fatal disease with higher mean viral loads in an animal } \\
\text { model. }\end{array}$ \\
\hline [78] & $\begin{array}{l}\text { Update on therapeutic options for } \\
\text { Middle East Respiratory Syn- } \\
\text { drome Coronavirus (MERS-CoV) }\end{array}$ & $\begin{array}{l}\text { Al-Tawfiq and } \\
\text { Memish }\end{array}$ & Saudi Arabia & 2017 & $\begin{array}{l}\text { (Review) } \\
\text { MPA mechanism of action - Direct and indirect antiviral } \\
\text { activity by modulation of IFN response } \\
\text { The use of mycophenolate in the common marmoset } \\
\text { animal model resulted in higher mortality than untreated } \\
\text { animals: Mortality rate was } 67 \% \text { (untreated and MMF } \\
\text { treated) at } 36 \text { h post inoculation versus } 0 \%-33 \% \text { (lopina- } \\
\text { vir/ ritonavir-treated and interferon- } \beta 1 \mathrm{~b} \text { - treated }\end{array}$ \\
\hline
\end{tabular}


Supplementary Table 7. Current studies investigating COVID-19/ other coronavirus strains and Mycophenolate. (continued)

\begin{tabular}{|c|c|c|c|c|c|}
\hline [79] & $\begin{array}{l}\text { Middle East Respiratory syndrome } \\
\text { coronavirus: Another zoonotic } \\
\text { betacoronavirus causing SARS- } \\
\text { like disease }\end{array}$ & Chan et al & $\begin{array}{l}\text { Hong Kong/ } \\
\text { China }\end{array}$ & 2015 & $\begin{array}{l}\text { (Review) } \\
\text { The combination of mycophenolic acid and interferon } \\
\text { beta } 1 \text { b shows synergistic activity against MERS-CoV in } \\
\text { Vero cells. The desirable pharmacokinetics of myco- } \\
\text { phenolic acid compared to ribavirin warrants further } \\
\text { evaluation, although the potential inhibitory effect on } \\
\text { the immune system and therefore neutralising antibody } \\
\text { production should be fully assessed in animal models } \\
\text { before use in humans. } \\
\text { A fatal case of MERS was reported in a renal trans- } \\
\text { plant recipient who was receiving antirejection therapy } \\
\text { consisting of prednisone, mycophenolate mofetil, and } \\
\text { cyclosporine, but the dosage, serum drug level of myco- } \\
\text { phenolate mofetil, and resulting lymphocyte count were } \\
\text { not reported }\end{array}$ \\
\hline [80] & $\begin{array}{l}\text { A review of candidate therapies } \\
\text { for Middle East respiratory syn- } \\
\text { drome from a molecular perspec- } \\
\text { tive. }\end{array}$ & Rabaan et al & Saudi Arabia & 2017 & $\begin{array}{l}\text { (Review) } \\
\text { Reiteration of the promising results of MPA in an in vitro } \\
\text { setting, however, the marmoset animal model resulted in } \\
\text { fatal disease and high viral loads. The authors therefore } \\
\text { state that MPA should be used with caution for treat- } \\
\text { ment of MERS-CoV. }\end{array}$ \\
\hline
\end{tabular}

The EC50 is the concentration of a drug that gives half-maximal response. The IC50 is the concentration of an inhibitor where the response (or binding) is reduced by half. These terms are referred to a few times within the summary table.

Supplementary Table 8. Current studies investigating COVID-19/ other coronavirus strains and Tacrolimus.

\begin{tabular}{|c|c|c|c|c|c|}
\hline Study Ref & Title & Authors & $\begin{array}{l}\text { Country of } \\
\text { study }\end{array}$ & Year & Summary of results \\
\hline [81] & $\begin{array}{l}\text { Replication of human } \\
\text { coronaviruses SARS-CoV, HCoV- } \\
\text { NL63 and HCoV-229E is inhibited } \\
\text { by the drug FK506 }\end{array}$ & $\begin{array}{l}\text { Carbajo- } \\
\text { Lozoya et al. }\end{array}$ & $\begin{array}{l}\text { Germany/ } \\
\text { Switzerland }\end{array}$ & 2012 & $\begin{array}{l}\text { Coronaviruses represent the group of RNA viruses with } \\
\text { the largest RNA genome to date therefore the develop- } \\
\text { ment of resistant mutants to targeted drugs remains a } \\
\text { concern. } \\
\text { Viral replication represents potential antiviral targets. } \\
\text { Study performed genome-wide SARS-CoV yeast-two-hy- } \\
\text { brid interaction screen with human cDNA libraries iden- } \\
\text { tifying FK506-binding proteins as interaction partners of } \\
\text { SARS-CoV non-structural protein } 1 \text { (Nsp1). } \\
\text { FK506-binding proteins bind the immunosuppressive } \\
\text { drug FK506 (tacrolimus). } \\
\text { Since Nsp1 interacts with FK506-binding proteins, in- } \\
\text { vestigated whether FK506 inhibits replication of human } \\
\text { coronaviruses. } \\
\text { VeroFM cells infected with SARS-CoV and other human } \\
\text { coronaviruses and treated with FK506. } \\
\text { Study found that FK506 inhibits the replication of SARS- } \\
\text { CoV, HCoV-NL63 and HCoV-229E at non-toxic, low- } \\
\text { micromolar concentrations with reduction in viral titers } \\
\text { to undetectable levels. } \\
\text { All human coronaviruses sensitive to FK506 indicat- } \\
\text { ing the involvement of FK506-binding proteins in viral } \\
\text { replication. }\end{array}$ \\
\hline
\end{tabular}


Supplementary Table 8. Current studies investigating COVID-19/ other coronavirus strains and Tacrolimus. (continued)

\begin{tabular}{|c|c|c|c|c|c|}
\hline [82] & $\begin{array}{l}\text { MERS CoV infection in two renal } \\
\text { transplant recipients: Case report }\end{array}$ & $\begin{array}{l}\text { Al Ghamdi } \\
\text { et al }\end{array}$ & Saudi Arabia & 2015 & $\begin{array}{l}\text { Pneumonia caused by MERS-CoV associated with severe } \\
\text { morbidity and mortality in immunocompromised patients. } \\
\text { Data on clinical picture in solid organ transplant recipi- } \\
\text { ents and effect of anti-rejection immunosuppressive } \\
\text { regimens unclear. } \\
30 \text {-year old patient with renal transplant on immunosup- } \\
\text { pressive regimen of tacrolimus. } \\
\text { Tested positive for MERS CoV through nasopharyngeal } \\
\text { swab. } \\
\text { Received antibacterial therapy and mycophenolate } \\
\text { mofetil dose reduced and underwent full recovery. } \\
\text { Difficult to pinpoint why made full recovery compared to } \\
\text { other case study (not on tacrolimus) who died. }\end{array}$ \\
\hline [83] & $\begin{array}{l}\text { Human coronavirus NL63 } \\
\text { replication is cyclophilin } \\
\text { A-dependent and inhibited by } \\
\text { non-immunosuppressive } \\
\text { cyclosporine A-derivatives } \\
\text { including Alisporivir }\end{array}$ & $\begin{array}{l}\text { Carbajo- } \\
\text { Lozoya et al }\end{array}$ & Germany & 2014 & $\begin{array}{l}\text { Previous study shown that FK506 inhibit coronavirus } \\
\text { replication. } \\
\text { This study further shows that novel non- } \\
\text { immunosuppressive derivatives of CSA and FK506 } \\
\text { strongly inhibit the growth of human coronavirus HCoV- } \\
\text { NL63 at low-micromolar, non-cytotoxic concentrations } \\
\text { in cell culture. } \\
\text { HCoV-NL63 and HCoV-HKU1 discovered in } 2004 \text { and } \\
2005 \text { causing more severe lower respiratory tract } \\
\text { infections in younger children. } \\
\text { PPlase-independent activities of CsA and FK506 exerted } \\
\text { by gain-of-function, result from binary complexes formed } \\
\text { by binding of the drugs to FKBPs. Based on inhibition } \\
\text { of the protein phosphatase activity of calcineurin, these } \\
\text { complexes block the cellular calcineurin/NFAT pathway } \\
\text { thereby interfering with T-cell activation and IL-2 } \\
\text { production. } \\
\text { FK506 analogues (altered by side chain modification) }\end{array}$ \\
\hline
\end{tabular}

\section{References}

1. Zhu WJ, Wang J, and He XH, et al (2020) [The differential diagnosis of pulmonary infiltrates in cancer patients during the outbreak of the 2019 novel coronavirus disease] Zhonghua Zhong Liu Za Zhi 42(0) E008 PMID: 32133833

2. Li YH, Shen L, and Li J (2020) [Chemotherapy strategy for colorectal cancer under the outbreak of novel coronavirus pneumonia] Zhonghua Wei Chang Wai Ke Za Zhi 23(0) E004 PMID: 32100980

3. Nilsson A, Edner N, and Albert J, et al (2020) Fatal encephalitis associated with coronavirus OC43 in an immunocompromised child Infect Dis (Lond) 1-4

4. Barnard DL and Kumaki Y (2011) Recent developments in anti-severe acute respiratory syndrome coronavirus chemotherapy Future Virol 6(5) 615-631 https://doi.org/10.2217/fvl.11.33 PMID: 21765859 PMCID: 3136164

5. Aydin Köker S, Demirag B, and Tahta N, et al (2019) A 3-year retrospective study of the epidemiology of acute respiratory viral infections in pediatric patients with cancer undergoing chemotherapy J Pediatr Hematol Oncol 41(4) e242-e246 https://doi.org/10.1097/ MPH.0000000000001418 PMID: 30688827 
6. Soderman M, Rhedin S, and Tolfvenstam T, et al (2016) Frequent respiratory viral infections in children with febrile neutropenia-a prospective follow-up study PLoS One 11(6) e0157398 https://doi.org/10.1371/journal.pone.0157398

7. Pillaiyar T, Manickam M, and Namasivayam V, et al (2016) An overview of severe acute respiratory syndrome-coronavirus (SARS-CoV) 3CL protease inhibitors: peptidomimetics and small molecule chemotherapy J Med Chem 59(14) 6595-6628 https://doi.org/10.1021/ acs.jmedchem.5b01461 PMID: 26878082 PMCID: 7075650

8. Hijano DR, Maron G, and Hayden RT (2018) Respiratory viral infections in patients with cancer or undergoing hematopoietic cell transplant Front Microbiol 93097 https://doi.org/10.3389/fmicb.2018.03097

9. Milano F, Campbell AP, and Guthrie KA, et al (2010) Human rhinovirus and coronavirus detection among allogeneic hematopoietic stem cell transplantation recipients Blood 115(10) 2088-2094 https://doi.org/10.1182/blood-2009-09-244152 PMID: 20042728 PMCID: 2837322

10. Ogimi C, Waghmare AA, and Kuypers JM, et al (2017) Clinical significance of human coronavirus in bronchoalveolar lavage samples from hematopoietic cell transplant recipients and patients with hematologic malignancies Clin Infect Dis 64(11) 1532-1539 https://doi. org/10.1093/cid/cix160 PMID: 28329354 PMCID: 5434339

11. Ghosh AK, Xi K, and Johnson ME, et al (2007) Progress in anti-SARS coronavirus chemistry, biology and chemotherapy Annu Rep Med Chem 41 183-196 PMID: 19649165 PMCID: 2718771

12. LaFemina RL (2014) Alternative screening approaches for discovery of middle east respiratory syndrome coronavirus inhibitors Antimicrob Agents Chemother 58(8) 4251 https://doi.org/10.1128/AAC.03406-14 PMID: 24867994 PMCID: 4135998

13. Benites EC, Cabrini DP, and Silva AC, et al (2014) Acute respiratory viral infections in pediatric cancer patients undergoing chemotherapy J Pediatr (Rio J) 90(4) 370-376 https://doi.org/10.1016/j.jped.2014.01.006

14. Balzarini J (2007) Carbohydrate-binding agents: a potential future cornerstone for the chemotherapy of enveloped viruses? Antivir Chem Chemother 18(1) 1-11 https://doi.org/10.1177/095632020701800101 PMID: 17354647

15. Chen X, Chou CY, and Chang GG (2009) Thiopurine analogue inhibitors of severe acute respiratory syndrome-coronavirus papain-like protease, a deubiquitinating and delSGylating enzyme Antivir Chem Chemother 19(4) 151-156 https://doi. org/10.1177/095632020901900402 PMID: 19374142

16. Chebotkevich VN, Bessmel'tsev SS, and Volkov AV, et al (2006) [Molecular biology investigation of respiratory viruses as a factor of infectious complications in hemoblastosis and myelodepression] Vopr Onkol 52(4) 421-426 PMID: 17024815

17. Kesel AJ (2005) Synthesis of novel test compounds for antiviral chemotherapy of severe acute respiratory syndrome (SARS) Curr Med Chem 12(18) 2095-2162 https://doi.org/10.2174/0929867054637644 PMID: 16101496

18. Wang C, Pang B-S, and National Research Project for Sars BG (2003) [Dynamic changes and the meanings of blood cytokines in severe acute respiratory syndrome] Zhonghua jie he he hu xi za zhi = Zhonghua jiehe he huxi zazhi = Chin J Tuberc Respir Dis 26(10) 586-589

19. Jin $\mathrm{H}$, Xiao $\mathrm{C}$, and Chen Z, et al (2005) Induction of Th1 type response by DNA vaccinations with N, M, and E genes against SARS-CoV in mice Biochem Biophys Res Commun 328(4) 979-986 https://doi.org/10.1016/j.bbrc.2005.01.048 PMID: 15707974

20. Kesel AJ (2003) A system of protein target sequences for anti-RNA-viral chemotherapy by a vitamin B6-derived zinc-chelating trioxaadamantane-triol Bioorg Med Chem 11(21) 4599-4613 https://doi.org/10.1016/S0968-0896(03)00500-5 PMID: 14527557

21. Folz RJ and Elkordy MA (1999) Coronavirus pneumonia following autologous bone marrow transplantation for breast cancer Chest 115(3) 901-905 https://doi.org/10.1378/chest.115.3.901 PMID: 10084516

22. Fu Y, Cheng Y, and Wu Y (2020) Understanding SARS-CoV-2-mediated inflammatory responses: from mechanisms to potential therapeutic tools Virol Sin https://doi.org/10.1007/s12250-020-00207-4 PMID: 32125642 PMCID: 7035235 
23. Acland HM, Gunson DE, and Gillette DM (1983) Ulcerative duodenitis in foals Vet Pathol 20(6) 653-661 https://doi. org/10.1177/030098588302000601 PMID: 6649336

24. Fang L, Karakiulakis G, and Roth M (2020) Are patients with hypertension and diabetes mellitus at increased risk for COVID-19 infection? Lancet Respir Med https://doi.org/10.1016/S2213-2600(20)30116-8 PMID: 32171062

25. Lu H (2020) Drug treatment options for the 2019-new coronavirus (2019-nCoV) Biosci Trends https://doi.org/10.5582/bst.2020.01020

26. Lam CWK, Chan MHM, and Wong CK (2004) Severe acute respiratory syndrome: clinical and laboratory manifestations Clin Biochem $\operatorname{Rev} 25(2)$ 121-132

27. Mahmud-Al-Rafat A, Majumder A, and Taufiqur Rahman KM, et al (2019) Decoding the enigma of antiviral crisis: does one target molecule regulate all? Cytokine Cytokine 115 13-23 https://doi.org/10.1016/j.cyto.2018.12.008 PMID: 30616034

28. Wong SSY and Yuen K-Y (2008) The management of coronavirus infections with particular reference to SARS J Antimicrob Chemother 62(3) 437-441 https://doi.org/10.1093/jac/dkn243 PMID: 18565970

29. Zhang $\mathrm{X}$, Alekseev K, and Jung K, et al (2008) Cytokine responses in porcine respiratory coronavirus-infected pigs treated with corticosteroids as a model for severe acute respiratory syndrome J Virol82(9) 4420-4428 https://doi.org/10.1128/JVI.02190-07 PMID: 18287230 PMCID: 2293053

30. Amici C, Di Caro A, and Ciucci A, et al (2006) Indomethacin has a potent antiviral activity against SARS coronavirus Antivir Ther 11(8) 1021-1030

31. Hao D, He L-X, and Qu J-M, et al (2005) [A study of pulmonary inflammatory reaction induced by N-protein of SARS-CoV in rat models and effects of glucocorticoids on it] Zhonghua nei ke za zhi 44(12) 890-893

32. Chihrin S and Loutfy MR (2005) Overview of antiviral and anti-inflammatory treatment for severe acute respiratory syndrome Expert Rev Anti-infect Ther 3(2) 251-262 https://doi.org/10.1586/14787210.3.2.251 PMID: 15918782

33. Cinatl J, Jr., Michaelis M, and Morgenstern B, et al (2005) High-dose hydrocortisone reduces expression of the pro-inflammatory chemokines CXCL8 and CXCL10 in SARS coronavirus-infected intestinal cells Int J Mol Med 15(2) 323-327 PMID: 15647850

34. Wong CK, Lam CWK, and Wu AKL, et al (2004) Plasma inflammatory cytokines and chemokines in severe acute respiratory syndrome Clin Exp Immunol 136(1) 95-103 https://doi.org/10.1111/j.1365-2249.2004.02415.x PMID: 15030519 PMCID: 1808997

35. Zhao Z, Zhang F, and Xu M, et al (2003) Description and clinical treatment of an early outbreak of severe acute respiratory syndrome (SARS) in Guangzhou, PR China J Med Microbiol 52(Pt 8) 715-720 https://doi.org/10.1099/jmm.0.05320-0 PMID: 12867568

36. Tobinick E (2004) TNF-alpha inhibition for potential therapeutic modulation of SARS coronavirus infection Curr Med Res Opin 20(1) 39-40 https://doi.org/10.1185/030079903125002757 PMID: 14741070

37. Atanasova K, Van Gucht S, and Van Reeth K (2010) Anti-TNF-alpha therapy does not ameliorate disease in a model of acute virus-endotoxin mediated respiratory disease in pigs Vet Immunol Immunopathol 137(1-2) 12-9 https://doi.org/10.1016/j.vetimm.2010.04.003 PMID: 20466438 PMCID: 2922464

38. Gao Y, Li T, and Han M, et al (2020) Diagnostic utility of clinical laboratory data determinations for patients with the severe COVID-19 J Med Virol https://doi.org/10.1002/jmv.25770 PMID: 32181911

39. Conti P, Ronconi G, and Caraffa A, et al (2020) Induction of pro-inflammatory cytokines (IL-1 and IL-6) and lung inflammation by COVID-19: anti-inflammatory strategies J Biol Regul Homeost Agents 34(2) pii:1

40. Yamaya M, Nishimura H, and Deng X, et al (2020) Inhibitory effects of glycopyrronium, formoterol, and budesonide on coronavirus HCoV-229E replication and cytokine production by primary cultures of human nasal and tracheal epithelial cells Respir Investig https:// doi.org/10.1016/j.resinv.2019.12.005 PMID: 32094077

41. Chen L, Liu HG, and Liu W, et al (2020) [Analysis of clinical features of 29 patients with 2019 novel coronavirus pneumonia] Zhonghua jie he he hu xi za zhi = Zhonghua jiehe he huxi zazhi = Chin J Tuberc Respir Dis 43(0) E005 
42. Kim ES, Choe PG, and Park WB, et al (2016) Clinical progression and cytokine profiles of middle east respiratory syndrome coronavirus infection J Korean Medi Sci 31(11) 1717-1725 https://doi.org/10.3346/jkms.2016.31.11.1717

43. Li Y, Chen M, and Cao H, et al (2013) Extraordinary GU-rich single-strand RNA identified from SARS coronavirus contributes an excessive innate immune response Microb Infect 15(2) 88-95 https://doi.org/10.1016/j.micinf.2012.10.008

44. Liao Y, Wang $X$, and Huang M, et al (2011) Regulation of the p38 mitogen-activated protein kinase and dual-specificity phosphatase 1 feedback loop modulates the induction of interleukin 6 and 8 in cells infected with coronavirus infectious bronchitis virus Virology 420(2) 106-116 https://doi.org/10.1016/j.virol.2011.09.003 PMID: 21959016

45. Day CW, Baric R, and Cai SX, et al (2009) A new mouse-adapted strain of SARS-CoV as a lethal model for evaluating antiviral agents in vitro and in vivo Virology 395(2) 210-222 https://doi.org/10.1016/j.virol.2009.09.023 PMID: 19853271 PMCID: 2787736

46. Ishii $\mathrm{K}$, Hasegawa $\mathrm{H}$, and Nagata $\mathrm{N}$, et al Neutralizing antibody against severe acute respiratory syndrome (SARS)-coronavirus spike is highly effective for the protection of mice in the murine SARS model Microbiol Immunol 53(2) 75-82 PMID: 19291090

47. Yoshikawa T, Hill T, and Li K, et al (2009) Severe acute respiratory syndrome (SARS) coronavirus-induced lung epithelial cytokines exacerbate SARS pathogenesis by modulating intrinsic functions of monocyte-derived macrophages and dendritic cells $J$ Virol 83(7) 3039-3048 https://doi.org/10.1128/JVI.01792-08 PMCID: 2655569

48. Zhang X, Wu K, and Wang D, et al (2007) Nucleocapsid protein of SARS-CoV activates interleukin-6 expression through cellular transcription factor NF-kappaB Virology 365(2) 324-335 https://doi.org/10.1016/j.virol.2007.04.009 PMID: 17490702

49. Okabayashi T, Kariwa H, and Yokota S-I, et al (2006) Cytokine regulation in SARS coronavirus infection compared to other respiratory virus infections J Med Virol 78(4) 417-424 https://doi.org/10.1002/jmv.20556 PMID: 16482545

50. Sheng W-H, Chiang B-L, and Chang S-C, et al (2005) Clinical manifestations and inflammatory cytokine responses in patients with severe acute respiratory syndrome J Formosan Med Assoc = Taiwan yi zhi 104(10) 715-723 PMID: 16385373

51. Tseng C-TK, Perrone LA, and Zhu H, et al (2005) Severe acute respiratory syndrome and the innate immune responses: modulation of effector cell function without productive infection J Immunol 174(12) 7977-7985 https://doi.org/10.4049/jimmunol.174.12.7977 PMID: 15944304

52. Huang K-J, Su I-J, and Theron M, et al (2005) An interferon-gamma-related cytokine storm in SARS patients J Med Virol 75(2) 185-194 https://doi.org/10.1002/jmv.20255

53. Wang W-K, Chen S-Y, and Liu IJ, et al (2004) Temporal relationship of viral load, ribavirin, interleukin (IL)-6, IL-8, and clinical progression in patients with severe acute respiratory syndrome Clin Infect Dis 39(7) 1071-1075 https://doi.org/10.1086/423808 PMID: 15472864

54. Zhang Y, Li J, and Zhan Y, et al (2004) Analysis of serum cytokines in patients with severe acute respiratory syndrome Infect Immun 72(8) 4410-4415 https://doi.org/10.1128/IAI.72.8.4410-4415.2004 PMID: 15271897 PMCID: 470699

55. Wang C and Pang B (2003) Dynamic changes and the meanings of blood cytokines in severe acute respiratory syndrome Chin J Tuberc Respir Dis 26(10) 586-589

56. Ng PC, Lam CWK, and Li AM, et al (2004) Inflammatory cytokine profile in children with severe acute respiratory syndrome Pediatrics 113 e7-e14 https://doi.org/10.1542/peds.113.1.e7 PMID: 14702488

57. Richardson P, Griffin I, and Tucker C, et al (2020) Baricitinib as potential treatment for 2019-nCoV acute respiratory disease Lancet 395(10223) e30-e1 https://doi.org/10.1016/S0140-6736(20)30304-4 PMID: 32032529

58. Chen N, Zhou M, and Dong X, et al (2020) Epidemiological and clinical characteristics of 99 cases of 2019 novel coronavirus pneumonia in Wuhan, China: a descriptive study Lancet 395(10223) 507-513 https://doi.org/10.1016/S0140-6736(20)30211-7 PMID: 32007143

59. Ma Y, Wang C, and Xue M, et al (2018) The coronavirus transmissible gastroenteritis virus evades the type I interferon response through IRE1alpha-mediated manipulation of the microRNA miR-30a-5p/SOCS1/3 axis J Virol 92(22) https://doi.org/10.1128/JVI.00728-18 
60. Yang C-W, Lee Y-Z, and Hsu H-Y, et al (2017) Targeting coronaviral replication and cellular JAK2 mediated dominant NF-KB activation for comprehensive and ultimate inhibition of coronaviral activity Sci Rep 7(1) 4105 https://doi.org/10.1038/s41598-017-04203-9 PMID: 28642467 PMCID: 5481340

61. Wathelet MG, Orr M, and Frieman MB, et al (2007) Severe acute respiratory syndrome coronavirus evades antiviral signaling: role of nsp1 and rational design of an attenuated strain J Virol 81(21) 11620-11633 https://doi.org/10.1128/JVI.00702-07 PMID: 17715225 PMCID: 2168762

62. Chen L, Liu HG, and Liu W, et al (2020) [Analysis of clinical features of 29 patients with 2019 novel coronavirus pneumonia] Zhonghua jie he he hu xi za zhi = Zhonghua jiehe he huxi zazhi = Chin J Tuberc Respir Dis 43(0) E005

63. Miura TA, Wang J, and Holmes KV, et al (2007) Rat coronaviruses infect rat alveolar type I epithelial cells and induce expression of CXC chemokines Virology 369(2) 288-298 https://doi.org/10.1016/j.virol.2007.07.030 PMID: 17804032 PMCID: 2170429

64. Zalinger ZB, Elliott R, and Weiss SR (2017) Role of the inflammasome-related cytokines II-1 and II-18 during infection with murine coronavirus J Neurovirol 23(6) 845-854 https://doi.org/10.1007/s13365-017-0574-4 PMID: 28895072 PMCID: 5726909

65. Chen IY, Moriyama M, and Chang M-F, et al (2019) Severe acute respiratory syndrome coronavirus viroporin 3a activates the nlrp3 inflammasome Front Microbiol 1050 https://doi.org/10.3389/fmicb.2019.00050 PMID: 30761102 PMCID: 6361828

66. Kritas SK, Ronconi G, and Caraffa A, et al (2020) Mast cells contribute to coronavirus-induced inflammation: new anti-inflammatory strategy J Biol Regul Homeostat Agents 34(1)

67. Zhu M (2004) SARS immunity and vaccination Cell Mol Immunol 1(3) 193-198

68. Hart BJ, Dyall J, and Postnikova E, et al (2014) Interferon-beta and mycophenolic acid are potent inhibitors of Middle East respiratory syndrome coronavirus in cell-based assays J Gen Virol 95(Pt 3) 571-577 https://doi.org/10.1099/vir.0.061911-0 PMCID: 3929173

69. Lin MH, Moses DC, and Hsieh CH, et al (2018) Disulfiram can inhibit MERS and SARS coronavirus papain-like proteases via different modes Antiviral Res 150 155-163 https://doi.org/10.1016/j.antiviral.2017.12.015 PMID: 29289665

70. Cheng KW, Cheng SC, and Chen WY, et al (2015) Thiopurine analogs and mycophenolic acid synergistically inhibit the papain-like protease of Middle East respiratory syndrome coronavirus Antiviral Res 115 9-16 https://doi.org/10.1016/j.antiviral.2014.12.011

71. Chan JF, Chan KH, and Kao RY, et al (2013) Broad-spectrum antivirals for the emerging Middle East respiratory syndrome coronavirus J Infect 67(6) 606-616 https://doi.org/10.1016/j.jinf.2013.09.029 PMID: 24096239

72. Shen L, Niu J, and Wang C, et al (2019) High-throughput screening and identification of potent broad-spectrum inhibitors of coronaviruses J Virol 93(12) https://doi.org/10.1128/JVI.00023-19

73. Cinatl J, Morgenstern B, and Bauer G, et al (2003) Glycyrrhizin, an active component of liquorice roots, and replication of SARS-associated coronavirus Lancet 361(9374) 2045-2046 https://doi.org/10.1016/S0140-6736(03)13615-X PMID: 12814717

74. Al Ghamdi M, Alghamdi KM, and Ghandoora Y, et al (2016) Treatment outcomes for patients with Middle Eastern Respiratory Syndrome Coronavirus (MERS CoV) infection at a coronavirus referral center in the Kingdom of Saudi Arabia BMC Infect Dis 16(1) 174 https://doi. org/10.1186/s12879-016-1492-4 PMID: 27097824 PMCID: 4839124

75. Chan JF, Yao Y, and Yeung ML, et al (2015) Treatment with lopinavir/ritonavir or interferon-beta1b improves outcome of MERS-CoV infection in a nonhuman primate model of common marmoset $J$ Infect Dis 212(12) 1904-1913 https://doi.org/10.1093/infdis/jiv392 PMID: 26198719

76. Barnard DL, Day CW, and Bailey K, et al (2006) Enhancement of the infectivity of SARS-CoV in BALB/c mice by IMP dehydrogenase inhibitors, including ribavirin Antiviral Res 71(1) 53-63 https://doi.org/10.1016/j.antiviral.2006.03.001 PMID: 16621037

77. Mo Y and Fisher D (2016) A review of treatment modalities for Middle East Respiratory Syndrome J Antimicrob Chemother 71(12) 3340-3350 https://doi.org/10.1093/jac/dkw338 PMID: 27585965 
78. Al-Tawfiq JA and Memish ZA (2017) Update on therapeutic options for Middle East Respiratory Syndrome Coronavirus (MERS-CoV) Expert Rev Anti Infect Ther 15(3) 269-275 https://doi.org/10.1080/14787210.2017.1271712

79. Chan JF, Lau SK, and To KK, et al (2015) Middle East respiratory syndrome coronavirus: another zoonotic betacoronavirus causing SARS-like disease Clin Microbiol Rev 28(2) 465-522 https://doi.org/10.1128/CMR.00102-14 PMID: 25810418 PMCID: 4402954

80. Rabaan AA, Alahmed SH, and Bazzi AM, et al (2017) A review of candidate therapies for Middle East respiratory syndrome from a molecular perspective J Med Microbiol 66(9) 1261-1274 https://doi.org/10.1099/jmm.0.000565 PMID: 28855003 PMCID: 7079582

81. Carbajo-Lozoya J, Müller MA, and Kallies S, et al (2012) Replication of human coronaviruses SARS-CoV, HCoV-NL63 and HCoV-229E is inhibited by the drug FK506 Virus Res 165(1) 112-117 https://doi.org/10.1016/j.virusres.2012.02.002 PMID: 22349148

82. AlGhamdi M, Mushtaq F, and Awn N, et al (2015) MERS CoV infection in two renal transplant recipients: case report Am J Transplant 15(4) 1101-1104 https://doi.org/10.1111/ajt.13085 PMID: 25716741

83. Carbajo-Lozoya J, Ma-Lauer Y, and Malesevic M, et al Human coronavirus NL63 replication is cyclophilin A-dependent and inhibited by non-immunosuppressive cyclosporine A-derivatives including Alisporivir Virus Res 184 44-53 PMID: 24566223 